\title{
The Netherlands and the United Kingdom: A European Unemployment Miracle?
}

\author{
Steve Nickell \\ Centre for Economic Performance \\ London School of Economics \\ Jan van Ours \\ CentER for Economic Research \\ Department of Economics, Tilburg University \\ Institute for Labour Studies (OSA) and CEPR
}

November 1999

We are most grateful to Tanvi Desai for her assistance with some of the UK data and to Michele Belot and Joost Lebens for their assistance with some of the NL data.

This paper was presented in Frankfurt at the Economic Policy Panel Meeting, April 9, 1999 and in Ottawa at the CSLS Conference on the Structural Aspects of Unemployment in Canada, April 23, 1999. We have benefited from discussions during these meetings and in particular from comments by David Card, Harry Huizinga, Peter Kuhn, Danny Quah and Charles Wyplosz. We also thank Joop Hartog for his comments on a previous version of the paper. 
The unemployment rates in both the UK and the NL have declined substantially since the early 1980s. In this paper we argue that this is because of a significant reduction in the equilibrium unemployment rate, which was itself due to combinations of supply-oriented policies. The combinations are partly overlapping and partly differing between the two countries. The main difference is in wage negotiations. Where the Dutch unions were already co-operative, British unions were made to co-operate. The main overlap is in the popularity of part-time work and the re-enforcement of financial incentives for work for unemployed workers collecting benefits. 


\section{INTRODUCTION}

Ever since the increase at the beginning of the 1980s unemployment in the European Union has been persistently high. Now, at the end of the 1990s, unemployment is slowly declining but still averages about $10 \%$ of the working population. However, not every European country has the same poor labour performance. In recent years, much has been made of the relatively good performance of the job market in the Netherlands (NL) and the UK, particularly on the unemployment front. The main questions we address in this paper are whether the NL and the UK really have had such an outstanding labour market performance, if so why this is the case and whether there are lessons to be learned for other countries. Our strategy is to use the outcome of some recent international comparisons to identify potential determinants of labour market performance and to investigate in detail to what extent these determinants play a role in the specific labour markets of the NL and the UK.

As can be seen from Figure 1, in the early 1980s standardised unemployment rates in the NL and the UK were well above the EU average. By the late 1980s unemployment in both countries had fallen to the EU average and by the late 1990s it was well below. This divergence has been proceeding steadily in the NL from 1990 whereas in the UK unemployment only started to move below the EU average in 1993. Figure 2 shows that on average EU employment declined at the beginning of the 1990s, increased again in the second half of the 1990s to reach a level at the end of the 1990s comparable to the level in 1990. Whereas in the UK employment moves along the same lines, in the NL there is a remarkable increase in employment. In the course of the 1990s, it increased by about $15-20 \%$.

In the light of these broad trends, it is worth looking more closely at recent developments in both unemployment and non-employment in the OECD countries to see how UK and NL compare with other good performers, such as the US. Recent developments are summarised in Tables 1 and 2. In Table 1, we present the pattern of standardised unemployment rates across the OECD since the early 1980s. On the basis of these numbers, in terms of the trend of unemployment over this period, the NL and the UK, along with Ireland and the US, are the best performers. Of course, countries like Austria and Norway have lower unemployment in every period than these countries, so, in some absolute sense, they are obviously performing better. But in terms of improvement, the NL and the UK appear to be doing well with unemployment in the former now comparing favourably with that in the US. 
While unemployment rates are very important, they may not tell the whole story because some countries systematically shift people out of unemployment into other non-working categories, notably disability and early retirement. Some believe this to be of major importance. Thus, as President Jacques Chirac of France remarked "if unemployment is lower in Britain than in France, it owes no thanks to the virtues of economic liberalism but because the English fiddle their figures" (Le Nouvel Observateur, Nov, 19-25, 1998). This suggests that we should also look at non-employment rates that refer to the percentage of the population of working age who are not employed. These figures basically capture unemployment, disability, early retirement, full-time education and other elements of non-participation, notably married women involved in childcare. In Table 2 we present non-employment rates for the prime-age group (25-54) and the older age group (55-64). We omit the 15-24 age group because the rates for this group are so strongly influenced by participation in full-time education. For the Netherlands, we see a dramatic decline in non-employment rates for the prime-age population, which reflects the rise in employment noted in Figure 2. However, it might be argued that this merely reflects a convergence to the sort of levels that are commonplace in most OECD countries outside the Catholic countries of Southern Europe and Ireland. In the UK, there is no strong trend. Furthermore, in the Netherlands, the older age group exhibits one of the highest non-employment rates in the OECD with only a slight downward trend since the early 1980s. The UK, while it has a significantly lower non-employment rate for this age group, exhibits no trend over the same period.

To summarise, in terms of unemployment rates, the Netherlands and the UK exhibit a marked downward trend in unemployment rates since the early 1980s. This is matched by only two other countries in the OECD, namely Ireland and the US. However some countries, such as Norway, have unemployment rates which have remained low throughout. In terms of nonemployment rates, the Netherlands has had a sharp decline in non-employment for the prime-age group as it moves towards the North European norm, but retains a very high level of nonemployment among older people. The UK exhibits no marked trends and has a pattern and level of prime-age non-employment that is a very similar to France and West Germany, for example. Overall, the Netherlands and the UK exhibit an above average performance although hardly miraculous. 
Why are the NL and the UK doing better now on the unemployment front than they were in the early 1980s? This is our main concern but it is associated with another question, namely why did unemployment rise so much from the late 1960s to the early 1980s in both countries? In order to confront these questions, it is worth noting at the outset that the changes in unemployment in which we are interested are both substantial and long lasting, so that we must focus on factors which influence the equilibrium rate of unemployment. This is the baseline level of unemployment such that if actual unemployment moves too far below it, then inflation starts rising. The equilibrium rate of unemployment cannot be changed with monetary, fiscal or exchange rate policy. What these policies can do is change the way in which actual unemployment fluctuates around the equilibrium rate. Nevertheless, the equilibrium rate may change from one decade to the next for other reasons. These include anything that systematically changes inflationary pressure in the economy at a given level of unemployment. So in order to explain the unemployment patterns, we need to point to a series of factors whose impact tended to raise inflationary pressure in the 1970s and early 1980s but have since turned around.

While both the NL and the UK have enjoyed some success in reducing unemployment since the early 1980s, as we have seen, their relative performance in getting the population of working age into jobs is somewhat less impressive. In order to explain this contrast, we must obviously investigate the key factors determining other categories of non-employment aside from unemployment. The remainder of our analysis is set up as follows. In Section 2 we present the theoretical and empirical background of our paper. We advocate that in order to understand recent developments in unemployment we must focus on the equilibrium unemployment rate. Only then we can give a meaningful interpretation of changes in actual unemployment rates. To do this, we present the results of previous international comparative studies on labour market performance. From these we conclude that the main candidates for explaining the unemployment miracle are the reduced power of the unions in wage negotiations, the increased importance of financial incentives in the labour market and active labour market policies.

In Section 3 we study developments in unemployment and non-employment in the NL and the UK in more detail. We start putting the recent development in perspective by giving a description of unemployment in the past decades. We also go more deeply into the unemployment and non-employment numbers, looking particularly at the differences between men and women, and different skill groups. Then in Section 4 we discuss the main institutional 
changes in the labour markets of the two countries which underlie the developments in unemployment and non-employment presented in the previous section. With regard to unemployment we focus on changes in union wage bargaining, the tax and benefit systems and active labour market policies. Here we attempt to quantify the relative sizes of the effects. Then we turn to non-employment, analysing separately the contrasting fortunes of men and women. For the latter we concentrate on participation and the role of part-time employment. For men, we focus on changes in the system of disability benefits and early retirement schemes. Finally, in Section 5 we present a general discussion of the reasons underlying the success of the NL and the UK in bringing down unemployment and the lessons for other countries.

\section{THE THEORETICAL AND EMPIRICAL BACKGROUND}

In order to understand the patterns of unemployment and non-employment described in the Introduction, it is helpful if we summarise what we know about these issues. We shall discuss in turn, aggregate unemployment and the equilibrium rate, the relative unemployment rates of particular groups and finally, non-employment more generally.

\subsection{Why do we have unemployment?}

Unemployment tends to fall when output expands faster than the growth potential of the economy and tends to rise when there is a relative contraction. Since unemployment is undesirable, why do the authorities simply not put in place an expansionary monetary and fiscal policy to reduce it substantially. The answer, basically, is that they are afraid of generating inflation. So, in practice, when unemployment gets "too low", the consequent rise in inflation tends to induce a policy shift in a contractionary direction. When it gets "too high", inflation tends to fall and this tends to induce a policy shift towards expansion. The baseline level of unemployment, which is neither "too high" nor "too low" and corresponds to stable inflation, is the equilibrium rate. As we have already noted, in order to understand the long-run shifts in unemployment which have occurred in the NL and the UK, we must pinpoint those factors which influence this equilibrium rate. 


\subsection{The determinants of the equilibrium rate}

As we have seen, the equilibrium unemployment rate is that rate which is associated with stable inflation. So any labour market factor that tends systemically to raise inflationary pressure in the labour market at a given level of unemployment will tend to increase the equilibrium rate. Interestingly enough, this will include anything that tends to shift the Beveridge Curve outwards (see Box 1). The Beveridge Curve is the downward sloping equilibrium relationship between vacancies and unemployment which holds in steady state. An outward shift tends to arise either because of a secular increase in the inflow of people into unemployment or because of a systematic decline in the ability or willingness of the unemployed to compete for and fill the available vacancies. It is important to recognise that there may be factors which raise inflationary pressure at given levels of unemployment, and hence raise the equilibrium rate, but do not shift the Beveridge Curve. It is simply that anything which shifts the Beveridge Curve will affect the equilibrium rate. Turning now to specifics, we shall analyse a series of factors which are particular relevant for our current purpose. These include unemployment benefits, wage setting, labour taxes, skill mismatch and employment protection.

\section{Box 1 here}

2.2.1 Benefits and active labour market policies. Unemployment benefits influence equilibrium unemployment via their impact on the effective supply of labour. A more generous benefit system will exert upward pressure on wages at given levels of unemployment both because it reduces the fear of job loss on the part of the existing employees and because the unemployed are more choosy about which jobs they will accept. Because of this, we should also expect more generous benefits to shift the Beveridge Curve out. Furthermore, long durations of entitlement may be expected to increase long-term unemployment. The impact of a relatively generous benefit system might be offset by suitable active policy measures whose purpose is to raise the effective labour supply. These operate either by making the unemployed more willing to accept jobs or by making them more attractive to prospective employers. If successful, they will shift the Beveridge Curve inwards.

Do we see any of these effects in practice? The impact of a generous benefit system on unemployment is well documented both in terms of its effect in lengthening the unemployment 
durations of individuals (see Layard et al., 1991, p.255/6; OECD, 1994, Chapter 8; Abbring et al., 1997) and its impact on unemployment in cross-country studies using both time series (see Layard et al., 1991, Chapter 9, Table 12; Blondal and Pearson, 1995) and cross-section (see Scarpetta, 1996; Nickell, 1997; Elmeskov et al., 1998) information. The accumulated evidence here is strong with most studies pointing in the same direction.

Concerning the impact of the duration of entitlement, again the evidence points conclusively to the fact that long-term benefits help create long-term unemployment (see, for example, Nickell, 1997, Table 6 or OECD, 1991, Chart 7.1 B). The final issue is whether or not the effects of a relatively generous benefit system can be offset by active labour market policies whose ostensible purpose is to make unemployed individuals more willing and able to return to work. The evidence here is as mixed as the policies. Cross-country comparisons do seem to generate fairly robust results in favour (see, for example, Scarpetta, 1996; Nickell, 1997; Elmeskov et al., 1998). However, looking at the evaluations of individual policies gives a less favourable impression (see Martin, 1998 for a useful summary). Basically, some types of programme work well and others do not work at all. We know a reasonable amount about what works but our knowledge is incomplete. However, we do know that combining a generous benefit system with well designed active labour market programmes and strictly applied search criteria and work tests for benefit eligibility will lead to lower unemployment levels than a system which provides benefits with few strings attached.

2.2.2 Unions, wage setting and minimum wages. Because of their ability to impose costs on firms, unions can raise wages. If most of the workforce is covered by union collective agreements, even if many are not union members, this will tend to add to overall inflationary pressure at given unemployment and raise its equilibrium level. As it happens, most workers in Europe do indeed have their wages set as a result of collective agreements negotiated between trade unions and employers. Furthermore there is a mass of evidence that unions force firms to pay higher wages than would be paid to similar workers in non-union firms (see Lewis, 1986 and Blanchflower, 1996, for useful surveys). Cross-country comparisons indicate that because unions increase wage pressure, they will, ceteris paribus, raise equilibrium unemployment. Furthermore, the more workers who are covered by union collective agreements, the bigger the effect (see Nickell and Layard, 1998, Table 15, for example). There are three factors that can mitigate the unfavourable impact of unionised collective bargaining on equilibrium 
unemployment. First, the government can enact legislation that directly weakens the power of unions in wage bargaining by, for example, restricting the right to strike. Second, unions are less able to raise wages in those firms that are subject to a high degree of national and international product market competition $^{2}$ (see Stewart, 1990; Abowd and Lemieux, 1993; Nickell et al., 1994, for example). Third, equilibrium unemployment will be lower if there is some institutional mechanism by which the parties to wage bargains take into account the macroeconomic, and particularly, the employment implications of the bargains they jointly strike. We refer to this as co-ordination, which may be achieved by government action at the central level or by the joint actions of groups of firms and unions. Evidence suggests that co-ordination can fully offset the negative effects of widespread unionised collective wage bargaining. (See Nickell and Layard, 1998 or OECD, 1997, Chapter 3).

Turning now to the impact of minimum wages, there is very little consensus on this question as a reading of Card and Krueger (1995) and its various reviews in the July '95 issue of the Industrial and Labor Relations Review readily indicates. Our reading of the evidence is that minimum wages are typically set low enough not to have a significant impact on adult male unemployment. However, in countries where the minimum is not adjusted for young people (e.g. France and Spain) or which have a very high payroll taxes (e.g. France and Italy), there is some evidence that youth unemployment rates are increased (see Dolado et al. 1996).

2.2.3 Labour taxes and commodity prices. Under this heading we include payroll taxes, income taxes and consumption taxes. Taxation on labour typically operates via the wedge between the real cost of a worker to the employer (which influences labour demand) and the real consumption wage of the worker (which influences labour supply). All three of the taxes mentioned above contribute to this wedge, as do commodity prices, in so far as most commodities are imported. What happens is that if workers wish to maintain their real after-tax purchasing power when the price of imported commodities goes up, wages must rise to compensate for the increase in consumer prices. Exactly the same argument applies if consumption taxes go up. If income taxes go up, they will equally need higher wages to sustain real after-tax purchasing power, and real labour costs will rise automatically if payroll taxes increase. So if any of these elements of the tax wedge increase, inflationary pressure, and hence the equilibrium unemployment rate, will go up if workers attempt to maintain their living standards. 
What of the evidence? Considering taxes first, there are two important questions. First, is unemployment affected by a shift of the tax burden from one element of the labour tax wedge to another (for example, a shift from payroll taxes to consumption taxes)? Second, is unemployment influenced by the labour tax burden overall?

To answer the first question we need to know whether different taxes exhibit differential rates of shifting onto labour. The time series results, many of which are summarised in Layard et al, (1991) p.210 and OECD (1994) p.247, show no clear pattern. However, in the multi-country investigations of Tyrväinen, reported in OECD (1994), Table 9.5, and of Robertson and Symons in OECD (1990), Annex 6A, there is no significant evidence that payroll, income or consumption taxes have a differential impact on labour costs and hence on unemployment. With regard to the second question, the evidence on the impact of the overall labour tax rate on unemployment is not clear-cut. The work of Robertson and Symons in OECD (1990), Annex 6, suggests that changes in the tax wedge have no long-run effects on labour cost although they do have substantial and long-lasting short-run effects. This is consistent with the microeconometric study by Gruber (1997) of the incidence of payroll taxation in Chile. He finds that in the longrun wages adjust fully to a sharp reduction in payroll tax rates and there is no employment effect whatever.

By contrast some large long-run effects of the tax wedge on labour costs and hence on unemployment are reported for some countries by, among others, Daveri and Tabellini (1997), Knoester and Van de Windt (1987) and Tyrväinen (1995). Unfortunately, as the summary table in Nickell and Layard (1998) (Table 18) indicates, there is a little in the way of a consistent pattern about these results. Perhaps more plausible numbers emerge from recent cross-country studies such as Scarpetta (1996), Nickell (1997) and Elmeskov et al. (1998) which reveal a small but significant long-run effect of the tax wedge on unemployment. In order to reduce unemployment by 1 percentage point, you need a reduction in labour tax rates of around 10 percentage points. On balance, therefore, there is probably some adverse effect of the overall labour tax burden on unemployment but its precise scale remains elusive.

With regard to commodity prices, a similar picture emerges. There is a considerable body of evidence that commodity prices in general, and the oil price in particular, have an impact on equilibrium unemployment, although whether it is permanent or temporary is less clear cut. The early work of Bruno and Sachs (1982) on input price shocks set the ball rolling and much 
multi-country evidence is reported in Bean et al. (1986) and Layard et al. (1991). Overall, there is agreement that the commodity price shocks of the 1970s had a significant role in the rise in unemployment across the OECD but whether their impact is permanent or temporary is not clear. 2.2.4 Skill mismatch. This refers to the situations of the kind where most firms have vacancies for skilled workers, say, and most of the unemployed who are looking for work are unskilled. Because the unemployed are not well matched to the vacancies, the firms will experience skilled labour shortages and this will generate inflationary pressure at any given level of unemployment and equilibrium unemployment will go up. Furthermore, the Beveridge Curve will shift out.

There is a lot of general evidence that mismatch between unemployed job seekers and available vacancies tends to raise unemployment (see Layard et al. 1991, Chapter 6). However, in the present context, we are particularly interested in skill mismatch, in part because in the UK there has been a substantial fall in the relative wages of the unskilled since 1980 and in part because of the relative worsening of the labour market position of the unskilled more widely. The cross-country evidence concerning changes over the last two decades is based on the work of Jackman et al (1997) and is summarised in Nickell and Layard (1998), Table 24. Basically, only the US and the UK have exhibited a significant increase in the excess demand for skilled labour and excess supply of unskilled labour over the last two decades. In the remaining seven OECD countries considered, including the Netherlands, there is no serious evidence of the demand for skilled workers outstripping the supply (or of the supply of unskilled workers outstripping the demand) in recent years. This is, of course, consistent with the fact that only in the US and the UK has there been a dramatic increase in the dispersion of earnings over the same period. Turning to the impact on unemployment, there is some evidence that these changes have influenced unemployment in the UK (See Nickell and Bell, 1995), contributing around 20 percent of the total equilibrium unemployment change from the late 1960s to the 1980s.

2.2.5 Employment protection. This covers all legal requirements concerning job security and the use of fixed term contracts. If the laws governing these matters become more stringent, this will tend to raise labour costs generally and labour turnover costs in particular. As with taxes on labour, if workers attempt to use their bargaining power to force firms to bear the general rise in labour costs generated by employment protection laws, this will raise equilibrium unemployment. If, however, wages are allowed to adjust to compensate the firms, then equilibrium unemployment will remain unchanged. However, even in this case, the relative 
costs of hiring and firing will go up and, as a consequence, the flows into and out of unemployment will tend to fall. So, even at unchanged equilibrium unemployment, short-term unemployment will tend to fall and long-term unemployment will tend to rise, exactly the pattern we see in practice (Nickell, 1997, Table 6). As for the overall impact of these offsetting effects, things are less clear. The evidence reported in Bentolila and Bertola (1990) and Nickell (1997) suggests there is no effect on the unemployment rate. However, some of the results in Scarpetta (1996) indicate a positive impact of employment protection on unemployment although this result is by no means robust.

2.2.6. Summary. In Table 3 we set out a list of the factors we have discussed in this section along with their impact on unemployment. When we come to look more closely at what has happened in the Netherlands and the UK, it is clear from Table 3 that we should focus particularly on changes in the benefit systems of the two countries and their wage bargaining structures. Some of the other factors are perhaps of less important although the evidence on skill imbalances in Britain should be pursued as well as recent changes in labour taxes. Two factors we shall ignore. Minimum wages barely existed in Britain over the relevant period and there is no evidence that the minimum wage system in the NL has made any contribution to the significant labour market changes. Employment protection has weakened in both the NL and the UK in the 1980s but on the basis of the evidence, we do not feel that this has had any significant impact on unemployment patterns over the last two decades.

\subsection{Unemployment rates among different groups}

Until now we have focused on the aggregate unemployment rate. But in order to obtain a complete picture of the changes that have occurred in recent years in the NL and the UK, we shall also be looking at the unemployment rates among different groups. So we need to understand the basic forces which cause these rates to differ significantly across the various groups which make up the working population. In the short run, unemployment rates in different categories will respond to movements in the relative demand for labour. If, for one reason or another, there is a shift in the demand for labour in favour of one group and against another, then in the short run the unemployment of the former group will tend to fall relative to that of the latter. However, in the longer term wages will adjust and the unemployment rates will tend to revert back to their original levels. 
Long-run unemployment differentials, such as those between skilled and unskilled workers or between young and prime-age workers arise for a number of reasons. First, there are differences in the degree of attachment to firms. For example, those in unskilled or marginal jobs tend to have the weakest attachment to firms, basically because they lack human capital, particularly of the specific type. So when demand for a firm's product falls, those in unskilled jobs are always the first to go. So, in the main, the unskilled and the young have a higher than average entry rate into unemployment. Second, their low wages ensure that their unemployment benefit replacement rates tend to be higher than average, reducing their work incentives ${ }^{3 .}$ Finally, any tendency for there to be a floor on wages will tend to raise the unemployment of the potentially low paid. Such floors on wages may arise because of minimum wage laws, the activities of unions or simply because some employers may find it distasteful or unprofitable to pay very poor wages.

\subsection{What determines the non-employment rate?}

The non-employed of working age consist of a wide variety of different groups who are not working for various different reasons. The main groups are the unemployed, the sick and disabled, full-time students, the early retired and those looking after families. We do not concern ourselves here with the under $25 \mathrm{~s}$, because so many of them are in full-time education, so aside from the unemployed, the significant groups are the sick, disabled and early retired among men and the non-participating married women who are looking after their families.

Considering the latter first, the participation and employment rates among married women have been rising steadily in more or less all OECD countries since 1950, this rise being driven, at least in part, by increasing job opportunities and rising real wages, both supported by anti-discrimination legislation of various kinds. Mincer (1985) gives a good overview of the basic forces at work although there are strong cross-country differences in the speed with which married women have entered the labour force which are due, in the main, to idiosyncratic social and cultural as well as economic factors.

Perhaps more interesting from our point of view are the forces governing the extent of sickness, disability and early retirement among men. Our interest is stimulated by the steady rise in these categories in both the Netherlands and the UK, which we shall discuss at some length in subsequent sections. The basic hypothesis we would propose here is that the rules governing 
entry and the benefits available are the driving forces behind the observed changes. What is the evidence here? Concerning early retirement, the work of Blondal and Scarpetta (1998) provides some very persuasive answers. There are enormous variations in the participation rates of older men (55-64) across the OECD and the analysis has been much assisted by the fact these variations were not apparent as recently as 1971, when nearly all countries (with the notable exception of Italy) had participation rates for this group in excess of 80 percent. Blondal and Scarpetta (1998) find that the major fact explaining the current variation and the consequent large changes since 1971 has been the structure of the social security system. Incentives to remain in the labour force vary widely, often as a result of misguided attempts to reduce labour supply as a response to increasing unemployment. One consequence of this is that participation rates for older men tend to be strongly negatively correlated with prime-age male unemployment rates. Another consequence is that if pension/social security systems were changed to be actuarially neutral, much of the observed decline in the participation rates among older men would be reversed.

A similar overall picture arises with sickness and disability. The evidence generated by comparing disability transfer systems across countries and by looking at the growth of disability programmes in the US leads Bound and Burkhauser (1997) to conclude that the key factors explaining numbers on the programme are the stringency of screening and the level of benefits. So it is important to recognise that the large increases in the numbers who receive disability benefits in many countries do not imply that the populations of these countries are becoming more susceptible to disease. On the contrary, all the countries are becoming healthier. In fact the key to these large increases lies in the fact that eligibility for disability status typically depends not just on health but on the labour market situation. For example, prior to the 1987 reform of the system, up to 50 percent of the disability enrolment in the NL was related to redundancy of workers. This allied to the fact that disability benefits tend to be higher and more secure than other non-employment benefits has led to large increases in recipients in those countries where entry into disability is not well controlled.

Having summarised what we know about cross-country patterns of unemployment and non-employment, next consider in detail what has been happening in the NL and the UK. 


\section{UNEMPLOYMENT AND NON-EMPLOYMENT IN NL AND UK}

Our purpose here is to provide a detailed picture of unemployment and non-employment in the NL and the UK in the post-war era, focussing particularly on the two most recent decades. The unemployment data for the NL are based on registered unemployment. The registered unemployed are those without a job of more than 12 hours per week who are registered at a public employment office and are directly available for a job of at least 12 hours per week. From 1988 onwards the figures are based on the registration at the public employment offices and a monthly labour force survey held among about 10,000 people ${ }^{4}$. For the UK we use data from the labour force surveys, in order to calculate unemployment rates according to the ILO definition ${ }^{5 .}$

\subsection{Unemployment in the past decades}

In this section, we consider developments in unemployment in the NL and the UK over recent decades. As shown in Figure 3 the development of unemployment in the NL and the UK is remarkably similar. From the second half of the 1950s up to the beginning of the 1970s unemployment in the NL and the UK was rather low. Even during the mild recession at the end of the 1950s the unemployment rates were below 3\%. In the first half of the 1960s the unemployment rate in the NL was around 1\%, while in the UK it was around 2-3\%. In the 1970s the unemployment rate in both countries started to increase to reach a level of about $6 \%$ in the mid 1970s after the first oil shock. In the second half of the 1970s it remained at around this level. After the second oil shock at the beginning of the 1980s unemployment exploded, reaching around $12 \%$ in 1983 in both countries. Subsequently unemployment steadily declined, a decline, which was only interrupted in the NL by the recession of 1994-95 and in the UK by the severe recession of 1991-93. In 1998 the unemployment rates of $4 \%$ in the NL and just over $6 \%$ in the UK, are down to the level of 1974, immediately after the first oil shock.

In the development of the Dutch labour market, several periods may be distinguished (see for example Hartog (1999)). In the first decades after the Second World War wages were under government control although over the years the control became less strict. Initially government simply determined the wage. Then there were so-called wage guidelines, which at first were national and later on allowed for industry differences. At the beginning of the 1960s government control was abolished, not because of a deliberate policy change but because the government was run over by the facts. Unemployment rates were so low that employers agreed to pay wages that 
were substantially higher than agreed at the national level. The 1960s saw the establishment of the welfare state. In 1963 the Law on Child Allowances was introduced, in 1965 the General Social Assistance Law, in 1966 the Law on Sickness Benefits and in 1967 the Law on Disability Benefits. Government still had its concerns about the development of wages. In 1970 the Law on Wage Formation was introduced, which allowed the government temporarily to freeze wage increases. The first major shock to the Dutch labour market was caused by the oil crisis of 1973. Unemployment started to increase. The Dutch government introduced an expansionary policy, financed by the abundant revenues from natural gas. The 1970s is the decade of the Dutch disease, characterised by inflation, expanding government expenditures and sharply declining profits. Despite several government interventions in the wage negotiations, wages increased substantially. The second oil crisis of 1979 fuelled a deterioration of the Dutch labour market and unemployment rose at an unprecedented speed. Although there is some debate, the year 1982 is considered by many to be a turning point. In that year, under the pressure of the seemingly endless rise in unemployment, a Central Agreement was reached between the labour unions and the employers' federation. In this so-called 'Wassenaar Agreement' and other agreements that were established at the same time, there were arrangements concerning wage restraint, reduction in working hours, restoration of profit levels of firms, labour market flexibility, early retirement and the creation of jobs. At the same time the government agreed to get its budget under control, reform social security and reduce taxes. In the course of the 1980s many of these agreements were implemented. In 1987 there was a major restructuring of unemployment benefits, sickness benefits, disability benefits and welfare benefits. The replacement ratios were lowered from 80 to $70 \%$ and eligibility rules were tightened. We return to this below.

\section{Box 2 here}

Turning to events in the UK, in the 1960s unemployment fluctuated around an equilibrium level of around 2.5\% (See Layard et al., 1991, pp. 435-48 and Nickell, 1999, Table 6 for details on the equilibrium rate in the UK). In the 1970s equilibrium unemployment started to rise as unions became stronger and workers attempted to maintain their living standards after the first oil shock. Until 1980 unemployment, at around 6\%, was sustained below the equilibrium rate of around $7.5 \%$ at the cost of rising inflation and a balance of payments deficit in the latter 
part of the period. Then in the first half of the 1980s, after the second oil shock, unemployment rose above the equilibrium rate of about $10 \%$ with falling inflation and a large payments surplus. As unemployment fell relative to a stable equilibrium rate in the late 1980s, inflation began to rise and the balance of payments went into deficit again. More recently the equilibrium rate appears to have fallen and currently, actual unemployment is probably fairly close to equilibrium.

Overall, therefore, in both the NL and the UK we have this significant decline in unemployment from the early 1980s to the late 1990s, the order of magnitude being around 5.7 percentage points in the NL and 4.1 percentage points in the UK (change from 1981-3 to 1995-8 in both cases). Given the long period and large apparent secular shifts in unemployment, this clearly suggests significant changes in the equilibrium rates, a hypothesis which is reinforced (see Box 1) by the clear leftward movement in the Beveridge Curves of both countries over the same period (see Figure $4 a, b$ ). The evolution of the size of the stock of unemployed is determined by the evolution of its two components, inflow and average duration. Here, the developments in the NL and the UK have been rather similar since the early 1980s. While the inflow rate in both countries has been highly cyclical, there has been no apparent secular shift from 1983 to the present time (See Nickell, 1999, Figure 5 and Abbring et al., 1998, Figure 1). In other words, in order to explain changes in the equilibrium rate and shifts in the Beveridge Curve, we cannot point to any secular reduction in the inflow rate (the parameter, $s$, in Box 1). What does explain the changes we consider in the next section after we have looked more closely at unemployment and non-employment among different groups.

\subsection{Unemployment and non-employment among specific groups.}

In the 1990s, unemployment for men in the NL has been lower than for women. The difference is almost stable at 1.2-1.3\%-points. In 1998 the unemployment rate of men was 3.7\%, the female unemployment rate was $4.8 \%$. As shown in Table 4 the pattern in the evolution of the two unemployment rates is very much the same. Both unemployment rates peak in 1995, while by 1998 they are below the rate of 1990. A similar pattern holds for all age groups, although it is clear that the fluctuations in unemployment rate are larger the younger the age of the unemployed workers. 
The average non-employment rate in the NL has gone down substantially since 1995 from $42 \%$ to $38 \%$ in 1998 . There is a very different pattern for men and women. Over the period 1990-98 the non-employment rate for men went down by 4\%-points, for women the decline was 10\%-points. ${ }^{6}$ The non-employment rate increases with age. In 1990 the male age group 25-34 years had a non-employment rate of $12 \%$, while the age group 45-54 years had a nonemployment rate of $18 \%$. The 55+ group has by far the highest non-employment rate of all male age groups; in 1990 this group of males had an average non-employment rate of 58\%. This high non-employment rate among the oldest workers has to do with disability and early retirement. We return to these phenomena in more detail in Section 4. The non-employment rate among females is substantially higher and increases rapidly with age. In 1990 the non-employment rate among the female age group 25-34 years was 47\%, while among the age group 45-54 years it was $67 \%$. The non-employment rate among the age group 55-64 was 89\%. The increasing nonemployment rate over the age categories has to do with the labour market participation of females, which declines rapidly with age. Over the 1990s there has been a remarkable decline in the non-employment rates for all age groups except for the oldest male workers.

For the UK, in the slump of the early 1980s, unemployment rates among men and women were much the same. In the 1970s, they tended to be somewhat higher for women. However, since that time, the unemployment rate for women has fallen substantially relative to that for men, so that it is the female labour market which has made a major contribution to the overall decline in the UK unemployment rate. This was particularly noticeable during the slump of the early 1990s when male unemployment peaked at 12.5 percent in the Spring of 1993 whereas female unemployment reached only 8 percent at the same time. As we saw in Table 2, the nonemployment rate among prime-age people in the UK has remained pretty stable since the late 1970s. But this hides very different patterns for men and women as we see in Table 4. Over this period, the non-employment rate among prime-age men has risen from 6.1 to 13.6 percent. By contrast, that among prime-age women has fallen from 40.0 to 28.6 percent. Since the total changes in non-employment have been rather small over this period, much of these changes are due to the rise in inactivity among prime-age men and the rise in labour market participation among prime-age women. The role of disability in the former is an issue we shall pursue. By contrast, for older people, the rise in non-employment among men since 1979 has not been offset 
by a significant fall in non-employment among women which remains stubbornly around 50 percent.

Table 4 also shows the differences in unemployment and non-employment rates by educational level. It is obvious that both in the NL and the UK the unemployment rates decline with educational level. Whereas in the NL the 1998 unemployment rate among workers with a higher education was $2.4 \%$, it was $12.9 \%$ for workers with primary education. The fluctuations are largest for the workers with primary education. In the 1990s their unemployment rates fluctuated between 15 and 19\%, while the unemployment rates of the workers with higher vocational training fluctuated between 3 and 5\%. As we can see from Table 4, in 1979, UK men had an unemployment advantage over women in all education groups, albeit only a small one for those without any qualifications. By 1985, UK men with low levels of education were really starting to lose out and by the early 1990s, UK men without qualifications were twice as likely to be unemployed as women in the same position. Over the last two decades, there has been a collapse in demand for unskilled workers, caused both by technical change and by competition from the Newly Industrialised Countries. Of course, there has also been a substantial fall in the supply of unskilled workers over the same period, but, in the 1980s, this did not keep pace in the UK with the fall in demand. On the other side of the coin, the rise in the demand for skilled workers appears to have outpaced supply over the same period (see Nickell and Layard, 1998, for details).

Turning to non-employment rates, it turns out that in the NL the decline is especially strong for workers with an education at a lower and intermediate level. This too has to do with the increasing participation rate of women. For the UK the key feature is the enormous increase in non-employment rates among prime-age men with no qualifications, so that by 1998, 35 percent of the relevant population were not working, an increase of nearly 400 percent since 1979. Furthermore, amazingly the increase continued year by year throughout the 1990s despite the substantial improvement in the labour market after 1993 when prime-age male unemployment fell by almost one-half. For prime-age women, substantial falls in non-employment occurred for all educational groups except the lowest where, as with the men, the rates went up continuously throughout the 1990s. Overall, the picture in the UK is one of non-employment rising among men and falling among women. But, for the group without qualifications, non-employment rates are rising for all groups with an enormous rise for prime-age men. 
Finally, we consider the unemployment rates among immigrants in the NL and among workers of different ethnic origin in the UK. At the moment in the NL about 1.5 million people are considered to be non-indigenous because they or at least one of their parents were born outside the NL. As counted in 1996 the largest groups of immigrants are Surinamese $(280,000)$, Turks (270,000), Moroccans $(225,000)$ and Antilleans $(95,000)$. The unemployment rate of immigrants is shown in Table 5. It is obvious that the unemployment rate of the immigrant groups is substantially higher than for the Dutch workers. In 1990 the unemployment rates of the former immigrant workers was about 35\%, while the unemployment rate of workers from former Dutch colonies was about 20\%. In the same year the unemployment rate among native Dutch workers was $5 \%$. The immigration of the past decades originates from two rather different processes (Van Ours and Veenman, 1999). The de-colonisation caused peaks in immigration in specific years while the hiring of immigrant workers - because of cyclical labour shortages turned out to have a structural character. Current labour market problems are to some extent related to the shift in immigration from a business cycle phenomenon to a structural process. In the 1960s immigrant workers were hired because the Dutch labour market was booming. The immigrant workers got jobs in industries with low paid labour. Since these industries were particularly hit by the economic recession of the 1980s, many immigrant workers lost their jobs to become long-term unemployed. The labour market position of many immigrant workers is weak because of their low educational level and lack of Dutch language skills. Therefore, it is remarkable that the unemployment rate among ethnic minorities has also gone down substantially since 1995 . For a long time immigrant workers were considered to be in a very difficult labour market position. In labour market policy immigrants have been one of the major target groups for active policy measures.

Table 5 also shows a break down of the unemployment patterns by ethnic origin for the UK. As we might expect, Whites have by far the lowest unemployment rates with Indians having somewhat higher rates and the other groups suffering massively higher unemployment. In fact, among all ethnic groups, men have done noticeably worse than women since 1979. In particular, among non-white groups, women had far higher unemployment rates than men in 1979 but by 1998 women's rates were comparable with and often lower than men's rates. Furthermore, in the last recession of the early 1990s, non-white men suffered enormous increases in unemployment although it came down equally rapidly as the economy recovered. So this particular group faces 
particularly high levels of job insecurity when times were bad. Overall then, the secular improvement in unemployment since the early 1980s has been particularly focussed on women with low skilled and non-white men lagging behind.

\subsection{Summary}

The key facts upon which we shall focus in the next section are first, the substantial secular decline in unemployment in both the NL and the UK from the early 1980s to the late 1990s. Second, the significant falls in the non-employment rates of women in both countries over the same period. Third, the very high (NL) and rapidly rising (UK) non-employment rates among older men. Finally, the rapidly rising non-employment rates among UK men with low levels of education.

\section{THE IMPACT OF THE MAIN INSTITUTIONAL CHANGES IN NL AND UK}

Our aim here is to analyse the relationship between the main institutional shifts in the NL and the UK in the last two decades and the most notable changes in the labour market. First we look in detail at the dramatic declines in the aggregate unemployment rates and we follow this with an analysis of the changes in the non-employment rates particularly among women and older men.

\subsection{Institutional changes and the aggregate unemployment rate}

As we saw in Section 3, aggregate unemployment rates in the NL have fallen by around 5.7 percentage points from 1981-3 to 1995-8 and in the UK by around 4.1 percentage points over the same period. These declines appear to reflect significant falls in the equilibrium unemployment rate. Following the discussion in Section 2 (See Summary Table 3), the key features of the labour market which we expect to influence the equilibrium unemployment rate are the wage bargaining system, the set of financial incentives implicit in the tax and social security system and the possible offsets due to active labour market policy. These have been the subjects of substantial changes in both the NL and the UK since the early 1980s, so we consider them in turn, starting with the systems of wage determination.

\subsubsection{Unions and wage bargaining}

The developments in union density in the NL and the UK are shown in Figure 5. In the 1970s in the UK union density increased, while in the NL it remained stable. In the 1980s union density 
goes down in both countries. In the 1990s there is some recovery of union density in the NL, while the decline continues for the UK. This leads union density at the end of the 1990s to be approximately the same in both countries. However, there is a major difference in the coverage of union wage agreements. In the NL, union coverage has remained remarkably stable, going from $76 \%$ in 1980 to $81 \%$ in 1994 . By contrast, in the UK it has collapsed from $70 \%$ in 1980 to $47 \%$ in 1994 and would be much lower in the private sector (see OECD, 1994, Ch.5; OECD, 1997, Ch.3). This extent of decline in coverage in the UK is almost unique in the OECD.

The most common opinion about the improvement of labour market performance in the NL is that it has to do with the co-operative nature of the unions. As Hartog (1999) puts it: "If there is anything like a Dutch model, it is the Dutch brand of corporatism, with consultation, coordination and bargaining over all important issues of socio-economic policy between union federations, employer federations and the government. The Dutch example shows that corporatist institutions are not synonymous with suffocating rigidity".

The Dutch economy was in a bad shape in the early 1980s. While unemployment rates were usually below the European average, in 1982-83 unemployment was above the European average. As the OECD (1998) puts it: "Confronted with a deeper crisis than most other European countries, the NL started its reform process earlier, with a greater scope for improvement". Economic growth in the remaining years of the 1980s was similar to the European average. The economic downturn in 1993 was mild in the NL and the recovery much stronger than in the rest of Europe. This is probably also why unions were modest and passive. There was wage moderation. This too may have been related to the restructuring of the benefit system. This wage moderation may also have been responsible for the boost in part-time employment.

The contrast between the roles of trade unions in the NL and the UK is marked. In the UK from the mid 60s into the early 70s there was a rise in trade union pressure on wages. This latter appears to have been part of an international shift which saw the number of industrial conflicts per employee in the OECD almost double in the period from 1967-1974. (Incidentally, this number has declined continuously since 1974 to less than half its 1967 level!) In the NL, after the early 1980s, unions understood the need for restraining inflationary pressure in the labour market and, because of the structure of the wage bargaining system, co-ordinated action was introduced to bring this about. By contrast, in the UK, with a completely decentralised union bargaining system, such co-ordinated action was more or less impossible even had union leaders 
been in favour of it (which they were not). However, the combination of tough new legislation reducing union bargaining power introduced in a series of measures in the 1980s and the decline in union representation in the private sector has, eventually, generated a significant reduction in inflationary pressure in the labour market, although this outcome has probably taken longer to achieve than in the NL.

\subsubsection{Financial incentives}

Figure 6 shows that the average unemployment benefit replacement ratio in the NL increased substantially in the 1970s and the early 1980s. Social security in the NL changed in 1987 when a new benefit system was introduced, which also affected unemployment benefits. As Figure 6 shows since then the replacement ratio has declined. One of the other important elements of the new system was the benefit sanction. If workers do not behave according to administrative rules a reduction of their benefit may be imposed. The main purpose is to increase the incentive to search and accept available jobs. The same type of benefit sanctions exists for welfare benefits. From research (Abbring, Van den Berg and Van Ours (1997) and Van den Berg, Van der Klaauw and Van Ours (1998)) it appears that benefit sanctions have a positive effect on the transition rate from unemployment to a job. In 1997-98 for unemployment benefit recipients the sanction rate (sanctions during benefit periods as a percentage of the average stock of benefit claims) in the NL of $36 \%$ was among the highest in OECD countries (in the UK is was about $10 \%$; see for other countries Grubb (1999)).

In August 1996 a new law on benefit sanctions was introduced. This was one of the reasons the sanction rate increased from 16\% in 1995 to 35\% in 1997 (at the introduction of the system of benefit sanctions the sanction rate was about 10\%; see for more details Boone and Van Ours (1999)). Under the new law people who receive benefits may get a reduction of their benefits if they don't follow the rules related to the benefits (not giving proper information, lack of effort in keeping a job, refusing job offers et cetera). Sometimes people have to pay back (part of) their benefits if they got them for the wrong reasons. Sometimes people have to pay a penalty ${ }^{7}$

The restructuring of the benefit system is certainly one of the main policy measures responsible for the 'Dutch miracle'. To give an impression of the strictness of the rules: Under the new rules, an unemployed person can look for a 'suitable' job for six months. A 'suitable' job is defined as a job according to the previous occupation, education and earnings. After six months the highly educated unemployed have to accept a job one level below their educational 
level. After one year that is extended to two educational levels. After 18 months of unemployment any job offer should be 'suitable'. For lower educated workers already after six months any job offer is 'suitable'. Generally, the longer the duration of unemployment the more workers have to adjust their preferences in terms of temporary work, less pay, longer commuting or even moving.

On the benefit front in the UK, things are not quite so clear cut. While it is true that the benefit system has become tougher, with replacement rates falling since the late 1970s (see Figure 6) and stiffer work testing, the housing benefit system, which pays rent and property taxes, has not moved in the same direction. Housing benefits, which are not included in the numbers in Figure 6, represent a substantial part of the income of the unemployed, particularly for single persons in high rent areas and are withdrawn at a rapid rate (65p for every $£ 1$ of net income) when they become employed. This represents a serious work disincentive. Furthermore, for most people, unemployment related benefits remain available indefinitely. This tends to encourage long-term unemployment and the consequent persistence of high unemployment after adverse shocks as the long-term unemployed find it very hard to get back into work. The welfare-to-work (New Deal) policies being introduced by the current Labour government are designed to counteract this problem (see Box 3 for details).

\section{Box 3 here}

Figure 7 presents the evolution of tax (and social security contribution) rates in the NL and the UK. In both countries there has been a decline since the mid 1980s. As we have already noted in Section 2 the impact of taxes on equilibrium unemployment is controversial. There is a general consensus that payroll taxes, per se, are of no special importance since they have more or less the same impact on the labour market as personal income taxes or VAT, for example. So there is no particular unemployment cost in switching taxes from VAT to employers' payrolls, say, since both taxes are shifted mainly onto workers ${ }^{8}$. This explains why Denmark and Australia do not appear to gain any special benefits on the unemployment front from having virtually no payroll taxes. However, the role of the overall tax rate on labour is less clear cut. As we reported in Section 2, it seems plausible that a decline in this rate has a modest impact on equilibrium unemployment, so the changes noted in Figure 7 have probably had some favourable impact in both countries in the recent past. 


\subsubsection{Active labour market policy}

Table 6 gives an indication of the importance of labour market programmes in the NL and the UK. As shown both in terms of active policy and in terms of passive policy the NL spend a substantial larger share than the UK does. The main difference both in terms of public expenditures as in terms of participants inflows has to do with subsidised employment. Especially in since 1996 this active labour market policy measure has increased substantially in the NL, ${ }^{9}$ although since the onset of the New Deal programmes in the UK in 1998, this is now currently rising fast in the UK as well. However, in the UK, active labour market policies have not had a significant role to play in the labour market improvements up to 1998.

In the NL the number of workers on socially purposeful jobs (WSW) hardly changed over the course of the 1990s. Socially purposeful jobs are intended for disabled workers and could be related to ordinary firms or to firms that specialise in these types of jobs ("social job centres'). The number of subsidised jobs (WIW) increased by about 40,000 in the 1990s. The WIW-jobs are intended for unemployed workers that are younger than 23 years and for longterm unemployed workers that collect benefits. Unemployed workers are hired by the local government, which may act as an intermediary for a job at a commercial firm. In theory the subsidised jobs last for a maximum of two years during which the unemployed get work experience. After a period on a subsidised job the unemployed are expected to find a regular job more quickly than they would have without it.

Apart from the WIW-jobs where the workers are hired by the local government there is an extensive programme of subsidised jobs, so-called Melkert jobs (named after the former Minister of Social Affairs and Employment). The aim is to provide 60,000 jobs for long-term unemployed, for 32 hours a week, at the minimum wage or slightly above. There are also wage subsidies for long-term unemployed: Employers who hire long-term unemployed, hire people on wages less than 115 percent of the legal minimum wage and provide training schemes are entitled to a cut in their tax bill of up to 6,000 Dutch guilders per year (one Dutch guilder is about 0.43 Euro). All in all, the number of workers on socially purposeful jobs or on subsidised jobs increased by about 100,000 in the 1990s. 


\subsubsection{Measuring the impact of the policy changes}

In this section we make some attempt to quantify the impact of the changes we have described on the equilibrium unemployment rates of the NL and the UK. Obviously our estimates, presented in Table 7, are rough and ready but it is helpful to look at some orders of magnitude. In the table, we consider six institutional changes from the early 80s to the mid 90s. These consist of three facets of the wage bargaining system (union coverage, density and coordination), the unemployment benefit replacement ratio, active labour market policies and the tax wedge. The impact of each of these on equilibrium unemployment is generated using the average coefficients taken from three panel data regressions reported in Nickell and Layard (1998), Scarpetta (1996) and Elemeskov et al. (1998). The magnitudes of the institutional changes are taken from various sources set out in note ii) of the table.

Looking first at changes in the NL, the total impact on equilibrium unemployment from the early 1980 s to the mid 1990 s is measured here to be a fall of 4.52 percentage points. This corresponds to a decline in actual unemployment from 1981-3 to 1995-8 of 5.7 percentage points, so it is of the correct order of magnitude. Turning to the institutional breakdown, changes in the wage bargaining structures generate a fall of 2.78 percentage points, changes in the tax/benefit system produce a fall of 0.65 percentage points and increases in active labour market policies yield a decline of 1.09 percentage points. Much of the fall corresponding to wage bargaining effects is due to the improved coordination following the Wassenaar Agreement with very little coming from any actual decline in unionisation as measured by density and coverage. In the UK the total measured effect on equilibrium unemployment reported in Table 7 is a decline of 3.76 percentage points which compares well with the actual decline of 4.1 percentage points from 1981-3 to 1995-8. As with the NL, the majority of the fall is due to changes in wage bargaining institutions, contributing 2.72 percentage points. However, by contrast with the NL, this is due entirely to the marked collapse in trade unionism in the UK as measured by the falls in density and coverage. There has been no change in coordination, indeed there is no coordination. Again by contrast with the NL, in the UK active labour market policies played no role up to 1998 and the remainder of the decline in equilibrium unemployment is due to the reduction in generosity of the benefit system and the fall in the tax wedge yielding a combined reduction of 1.2 percentage points. 
To summarise, much of the decline in equilibrium unemployment in the NL and the UK from the early 1980s to the mid 1990s is due to a combination of changes in the wage bargaining structures, the tax benefit system and active labour market policies. In the NL, major factors have been the improved coordination in wage bargaining, active labour market policies and the tightening of the benefit system. In the UK, key changes have been the marked decline in trade unionism, the tightening of the benefit system and the fall in the tax wedge. Finally, we ask the question, why is unemployment in the NL continuing to fall reaching a mere 3.4 percent at the time of writing whereas UK employment seems unlikely, at present, to fall much below 6 percent. In fact, equilibrium unemployment in the UK remains relatively high for at least two reasons. First, certain aspects of the UK benefit system still encourage unemployment in general and long-term unemployment in particular (notably the housing benefit system, particularly its impact on single people) and indefinite benefit availability for adult workers. This last will change with the introduction of the New Deal programme for older workers. Second, the substantial shift in demand against the unskilled and in favour of the skilled has outpaced the changes in relative supply. This means that even when unemployment is at a historically high level, inflationary pressures tend to appear in the labour market because of shortages of labour with the right kinds of skill. As we noted in (2.2.4), this has had a measurable impact in sustaining unemployment rates in the UK, whereas there is no evidence of any comparable effect in the NL.

\subsection{The fall in the non-employment rate of women}

As we noted in Section 3, there has been a substantial decline in the non-employment rates of women from the early 1980s in both the NL and the UK and this has been concentrated on the prime-age group (see Table 4). Why this has occurred is the topic of this section.

\subsubsection{Part-time labour and female participation}

One of the most interesting features of the female labour market in both the NL and the UK is the high and rising proportion of women who work part-time. In Table 8, we present the incidence of part-time labour in both countries. The incidence of part-time labour among women is substantially higher in the NL than in the UK. In 1998, 68\% of all Dutch employed women worked part-time, while in the UK $45 \%$ of all employed women worked part-time. In the NL the share of part-time labour is also increasing faster than in the UK. In both countries the incidence 
of part-time labour is substantially higher than the EU-average, which was 33\% in 1998. In fact, the NL has the highest incidence of part-time work among women in the whole of the OECD and the UK has the third highest (after Switzerland). This increase in part-time labour is intimately connected to the rise in female participation.

The participation rate of Dutch males was $80 \%$ in 1980, $79 \%$ in 1990 and again $80 \%$ in 1996. So for men there has been hardly any change in labour market participation over recent decades. For Dutch women the situation is completely different. The participation rate of Dutch women was $36 \%$ in 1980, $45 \%$ in 1990 and $53 \%$ in 1996. So, for females there has been a major increase in labour market participation. Furthermore, to a large extent part-time labour accords with the preferences of the workers. For example 78 percent of part-time women in the NL do not want a full-time job (OECD Jobs Study, Table 6.14).

The huge increase of part-time labour in the NL is a combination of several developments ${ }^{10}$. For a long time labour market participation of Dutch women was rather low compared to other European countries. The increase in female participation is partly a catch-up effect. Furthermore, barriers to part-time employment have been removed. In the Wassenaar agreement the unions gave up their resistance to part-time jobs. After that there has been a positive interaction between supply and demand. For employers part-time jobs are useful because they allow firms to allocate more labour towards weekly peak hours in production (for example in retailing) and because they attract new labour supply. Women who withdrew from the labour market for family reasons return to take up part-time jobs and women who would otherwise have left the labour market are now staying on in part-time jobs. So, the effective labour supply has increased. For women part-time jobs are useful because they allow them to combine paid work with childcare. It is our impression that the increase in part-time jobs has had a positive effect on employment growth. The mere fact that effective labour supply increased allowed many firms to expand their business. Part-time labour is not just a redistribution of a fixed amount of labour over a larger number of workers (the 'lump of labour fallacy'). In the period of rapid growth of part-time work the total number of hours worked in the NL has increased from 7.4 billion in 1985 to 8.6 billion in $1996^{11}$. Since many of the part-time jobs are taken by workers that came from outside the labour market it is more the non-employment rate than the unemployment rate that went down because of the increase in part-time labour. Nevertheless, we would argue that even the unemployment rate went down because of part-time labour. 
The decline in non-employment among UK-women recorded in Table 4 is mainly due to the rise in labour market participation rates among prime age women which has been going on in Britain since 1950. Starting out at below 50 per cent in 1951, the participation rate among women aged 25 to 54 had reached 66.7 per cent in 1983 and 75 per cent by 1997. This, incidentally, contrasts with the prime age male rate, which fell from 95.2 per cent in 1983 to 91.6 per cent in 1997. This rise in women's participation is common to more or less all OECD countries, although it has gone a lot further in Northern than in Southern Europe. There is a significant element of part-time work for women in the UK although the proportion has remained relatively stable since the late 1970 s with around 40 per cent working less than 30 hours per week. Furthermore, survey evidence suggests that nearly all these do not want a full-time job (94 per cent in 1989, see OECD Jobs Study, Table 6.14).

There is a definite contrast between the NL and the UK when it comes to the rise in female participation and part-time work. In the UK, the changes since the 1980s have been less dramatic and are simply a continuation of a process which started after World War II with some encouragement from the Anti-Discrimination Legislation in the early 1970s. There has never been much institutional opposition to part-time work and this is reflected by the fact that the proportion of women working part-time has risen by a mere 5 percentage points since 1973 (See OECD Employment Outlook, 1996, Table E). On the other hand, in the NL withdrawal of union opposition to part-time work in the Wassenaar Agreement generated a dramatic increase in parttime employment for women since that time, with the proportion of part-timers rising by over 20 percentage points.

\subsection{Non-employment rates for men}

As we saw in Section 3, the NL is notable for the very high non-employment rates among older men whereas in the UK these rates are not so high but they have been rising rapidly since the early 1980s. Furthermore, non-employment in the UK has also been increasing fast among prime-age men with low education. Much of this is due to the workings of the disability system and, in the NL, to official early retirement schemes. So it is these areas which we look at in detail. 


\subsubsection{Sickness, disability and early retirement}

In Table 9, we present sickness and disability rates in the NL and the UK. In the 1990s, we see that in the NL there was a combined rate of 16.1 percent of the population of working age, a truly enormous number. The equivalent rate in the UK in 1990 was only 5.8 percent but this has risen substantially since whereas in the NL the rate has significantly declined. So what has been going on?

In the NL in 1967 the comprehensive disability insurance for employees (WAO) was introduced. Under the terms of this law workers were insured against wage loss due to long-term disability. From then on if a worker became ill, he was allowed to claim a benefit under the illness scheme for a maximum period of one year. After that he could claim a disability benefit. Workers were entitled to disability benefits after a so-called disability examination, which consisted not only of a medical examination but also of an investigation of the labour market position of the worker. A worker could be considered disabled if there was no suitable job for him at his own educational level in his previous occupation. Furthermore, unemployment was "internalised", which means that those workers who were considered to be partially (more than 15\%) disabled, could collect full disability benefits because it was assumed that the partially disabled were doomed to remain unemployed. The benefit had a maximum of $80 \%$ of the wage in the last job. Disability benefits could be collected until age 65 .

Following the introduction of comprehensive disability insurance the number of workers collecting disability benefits increased massively. This huge rise eventually induced the government to change the structure of the disability benefit system. In 1981 the rules to calculate the wage in the last job changed: tips and overtime were no longer included in the calculations. In 1985-87 the maximum percentage of $80 \%$ of the previous wage was reduced to $70 \%$. In 1987 there was a major restructuring of the disability benefit system the main objective of which was to reduce the inflow into disability. The most important change was the abolition of the "internalisation of unemployment" rules. Partially disabled workers were considered as such and were expected to find a job or claim unemployment benefits for their remaining work capacity. In the early 1990s there were some further changes. For employers the disability insurance premium was experience rated, the disability examination no longer took the availability of suitable jobs with respect to education and previous occupation into consideration, the duration of the benefit was limited to five years after 
which a re-examination had to take place, and all disabled workers younger than 50 years had to be re-examined.

The reform of disability insurance was very important. Empirical studies find that before the 1987 reform of the disability benefit system up to $50 \%$ of the disability enrolment was related to redundancy of workers (see for an overview Hassink, Van Ours and Ridder (1997)). Hassink et al. (1997) demonstrated that at the end of the 1980s employers in the NL still used disability enrolment as an alternative to dismissals. They find that about $10 \%$ of the transitions into disability are due to redundancy of the worker. An implication of this result is that even after the social security reform of 1987, some employers and employees used disability enrolment to avoid dismissals. However, this type of behaviour is much less common than before the reform.

Since 1993 the number of workers collecting disability benefits slowly declined ${ }^{12}$. One of the reasons for this decline was the change in the benefit system. The main purpose was to reduce the number of beneficiaries. One of the measures was to re-examine disabled persons younger than 50 on the basis of a more stringent medical definition of disability. Apart from that wage subsidies were introduced. Employers who hire a (partly) disabled person can get a wage cost subsidy up to $25 \%$ of the gross wage of this person for a period of maximum 4 years. In 1997 there were 12,230 disabled workers employed with a wage cost subsidy. The average wage cost subsidy was around one third of the minimum wage. In addition employers could get a oneoff subsidy for on-the-job training at an average of about two months of the minimum wage.

Figure 8 shows that in the period 1994-1996 the outflow into disability was larger than the inflow into disability. The inflow into disability started declining in the beginning of the 1990s, a decline that coincides with the change in eligibility criteria. Over the same period the outflow increases slowly. In 1997 the old situation is restored and the inflow is again larger than the outflow. Thus it seems that the change in the system of disability benefits only had a temporary effect and did not solve the structural problem of the extremely high number of workers with disability benefits.

What happened in the UK? First, there are some incentives in the direction of disability. Benefits tend to be higher and more secure than on unemployment benefit, since there is little pressure to take up work. Furthermore, for those who work in the Employment Service, there are incentives to shift unemployed individuals onto disability schemes, particularly if they are hard to place in work. Second, it is clear from the report on disability by the National Audit Office 
(1989) that a variety of non-medical factors are taken into account by doctors involved in disability assessment. These include whether or not a claimant had been advised by the Employment Service to seek a statement of disability. However, it is only fair to add that the reasons underlying the dramatic rise in the sickness and disability numbers are not well understood. Indeed they are causing considerable anxiety to the UK Department of Social Security which is intent on reforming the system.

Table 10 shows the incidence of disability benefits in the NL and the sickness inactivity rate in the UK distinguished by age and gender ${ }^{13}$. The disability rates among Dutch men are substantially higher than among women. In 1998 the male disability rate was $10.1 \%$, whereas that among females was $6.7 \%$. The difference between males and females is age related. It appears that in the 1990s up to the age of 35 years there are hardly any differences between males and females. In 1998 of the males of age 25-35, 3\% collected disability benefits, while this was $3.5 \%$ for females. For higher age groups the incidence of disability benefits is substantially higher for males than for females. Of the males in age group 55-65, about one in three collects disability benefits, while for females in this age group this is $13-14 \%$. In the course of the 1990s disability rates have declined for most of the male age groups, while for females there has hardly been a change. For the UK, Table 10 presents the percentage of the relevant population who report themselves to be inactive because of sickness and ill health (which includes disability). Among the prime-aged, the numbers have risen by between three and four times since 1979, so that by 1998 there are about as many non-workers who are inactive because of sickness and disability as there are unemployed (i.e. seeking work). Furthermore, the numbers appear to increase independently of the state of the labour market, having risen by one and a half percentage point since 1993, despite the large fall in unemployment ${ }^{14}$ A similar picture appears among older workers. Back in 1979 only a tiny minority of the population aged 55-65 suffered from sickness and disability. By 1998, this group had risen to one-fifth.

These changes become even more drastic once we divide the population by educational attainment. Those without any qualifications, who currently make up around one-quarter of the population of working age, have seen the most enormous increases in sickness and disability. Among prime age UK men, a mere 3 per cent of the relevant population was inactive because of sickness and disability in 1979. By 1998, this had risen to 18 per cent. So nearly one-fifth of all prime age men in the UK population without educational qualifications are currently unable to 
work because they are invalids! And the same applies to just over one in seven women in the same category. Furthermore, these numbers have doubled since 1992 while there has been an economic boom. These are dramatic changes indeed and so, in both the NL and the UK, the operation of the sickness and disability system has been a major factor in explaining key features of the structure of non-employment rates. However, in the NL early retirement schemes have also contributed to the very high non-employment among older workers.

In the 1980 s in the NL, early retirement was introduced as an official scheme. The scheme turned out to be quite popular among elderly workers and the number of participants increased up to 127,000 in 1990 . During the 1990 s the number of workers in early retirement has not changed a lot. In 1998 there were 141,000 early retired workers. The number of women in early retirement is low (27,000 in 1998). This is because the number of female workers in high age categories is substantially lower than the number of males in the same age categories. So, although there has been an increase in early retirement during 1990s this can account for only a small fraction of the change in unemployment rates. Because of the popularity of the early retirement scheme and the changing demographic structure of the Dutch population that would substantially increase the number eligible workers, unions and employers have agreed slowly to increase the age at which workers become eligible.

Overall, therefore, changes in the structure of the systems governing sickness, disability and early retirement have had a dramatic impact on the history of inactivity rates among the working age population in both the NL and the UK. In particular the history of disability benefit in the NL is a textbook demonstration of the powerful impact of benefit incentives on behaviour.

\section{CONCLUSIONS: LESSONS TO BE LEARNED}

Both the UK and the NL have experienced a major decline in unemployment rates since the early 1980s. Furthermore, over the same period, the decline in unemployment rates was accompanied by a decline in non-employment rates. So, for both countries the declining unemployment is a real phenomenon and not just a result of a statistical redistribution of nonemployed workers from unemployment to other categories. Since in most other EU-countries such a decline in unemployment did not occur to the same extent there is something of an unemployment miracle here. In both countries the driving force underlying the declining 
unemployment rates has been the significant reduction in equilibrium unemployment since the early 1980s. In both countries, there have been significant changes in wage bargaining structures and the unemployment benefit system has become markedly less generous along with an increase in the pressure to take jobs. However, the NL has combined this change with an increase in expenditure on active labour market programmes to help the unemployed, which contrasts with a significant decline in such programmes in Britain, at least up until 1996 (see Martin, 1998, Table 1).

The success of the NL and the UK in bringing down unemployment from the disastrous heights of the early 1980s is a significant achievement. Some other aspects of the operation of their labour markets are less praiseworthy, notably the disability system. What, then, are the overall lessons which others in Europe might heed?

\section{Unions and wage bargaining}

The recent history of the NL and the UK emphasises the importance of wage bargaining systems. Since 1983, the unions in the NL have been very co-operative and they operate within a highly co-ordinated wage bargaining system. As a consequence, when the labour market starts to become tight, there is no excessive upward pressure on wages and this enables a low level of unemployment to be sustained. To a lesser extent, this has been achieved in the UK by reducing the wage bargaining power of unions via legislation and also because of the increasing weakness of unions in the private sector. The Dutch method is probably socially more desirable but the UK provides a lesson in a situation where bargaining is essentially decentralised and the institutions required for co-ordinated wage bargaining simply do not exist.

\section{Benefit systems}

There is no question that the gradual restructuring of the benefit systems of the NL and the UK has helped their economies to sustain lower levels of unemployment. Both countries have reduced benefits and have made the work test stricter. As complements to this, the Dutch have introduced, and the British are introducing, active labour market policies targeted on the long-term unemployed, with a view to eliminating this group. The New Deal programmes in Britain aim eventually to intercept all unemployed individuals at a certain duration point and insist that they take up a work or training alternative. We feel that this kind of restructuring to help push the long-term unemployed into work is a step in the right direction. 
However, more generally on the benefits front, one of the most important lessons of the UK in the 1980s and 1990s, and the NL in the 1970s and 1980s, is that the disability and sickness benefit systems must be kept under control with very stringent entry criteria. Over these periods, in both countries, there were enormous increases in the numbers on disability benefit that obviously did not correspond to secular declines in general health. The situation has now stabilised in the NL, albeit with very large numbers, but in the UK the figures are still rising. This whole debacle emphasises how important it is not to succumb to the temptation to reduce labour supply as a policy response to increasing unemployment.

\section{Employment flexibility}

One of the features of women's employment in the NL and the UK is the large proportion of part-time workers. Part-time work allows flexibility for both employers and employees and has enabled a very rapid build up of female employment, particularly in the NL. It is important to recognise that most part-time workers would not prefer a full-time job and that the elimination of barriers to part-time work has raised welfare significantly.

\section{Skills}

In the UK, but not in the NL, there is evidence that the equilibrium unemployment rate is higher than it need be because the shortfall in the supply of skilled workers as the labour market gets tight generates inflationary pressure. The problem in Britain is that the workforce has too many low-skill workers. For example, according to the OECD literary survey, which uses a common test, only around 10 per cent of the population of working age is at the lowest level of literacy in the NL compared with more than 22 per cent in the UK (see OECD, 1997a). This reveals the importance of providing good, basic education for the whole population rather than allowing the lower part of the ability range to miss out, as in the UK.

\section{So}

The unemployment rates in both the UK and the NL went down substantially because of a significant reduction of the equilibrium unemployment rate since the early 1980s. Combinations of supply-oriented policies are responsible for this. The combinations are partly overlapping and partly differing between the two countries. The main difference is in wage negotiations. Where the Dutch unions were already co-operative, British unions were made to co-operate. The main overlap is in the popularity of part-time work and the re-enforcement of financial incentives for work for unemployed workers collecting benefits. We have made an 
attempt (see 4.1.4) to quantify the separate contribution of each of the policy changes. However it is worth bearing in mind that our quantification may not be wholly reliable because policy changes are complementary. The effect of one policy depends on whether or not a different policy is implemented as well. So, as Freeman (1998) puts it: "To the extent that configurations of institutions or policies matter, the proper comparison across countries is between entire models, not between particular features". In other words, a change of institutions in the labour market is a package deal. 


\section{Endnotes}

1. This is the definition of the Phillips Curve which is now standard in macroeconomics. Originally, of course, it only referred to a wage equation.

2. Unions may overcome the problems of national product market competition by attempting to bargain wages for the whole industry (see the analysis in Calmfors and Driffill, 1988).

3. It is worth noting that in many countries without unemployment benefits systems, measured unemployment rates are higher for the well-educated, essentially because the uneducated cannot afford to be unemployed (see, for example, Bhalotra, 1993, for India and Nickell and Bell, 1995, Table 2a, for Italy).

4. The unemployment rate based on this information is about $0.3 \%$ - points higher than the ILO-unemployment rate.

5. The unemployment rate according to the ILO-definition is currently about $1.5 \%$-points higher than the official unemployment rates. This is mainly due to the fact that many unemployed married women are not entitled to benefits.

6. In the calculation of the non-employment rates jobs with a working time of less than 12 hours per week have been omitted. If these jobs would be included the non-employment rate of males would decline by $4 \%$-points, while the non-employment rate of females would decline by $10 \%$-points. The share of these jobs with limited working hours has been quite constant during the 1990s. Most of the action for females is in the jobs of 1234 hours per week.

7. To give an idea about the system, these are some statistics for 1997 (excluding people on welfare): About 11,000 penalties were imposed where the average penalty was 312 Dutch guilders $(83 \%$ of all penalties were given to people with unemployment benefits, other important categories are sickness benefits and disability). Furthermore, about 172,000 sanctions were imposed (of which 16,054 because of lack of effort to keep their job: lost their benefits completely, 5,354 because of lack of effort to keep their job: $50 \%$ reduction of benefit over 6 months, and 2,403 because of refusal of job offer: lost their benefits completely. Finally, in some 153,000 cases benefits had to be paid back, where the 
average amount was 1,562 Dutch guilders and about 50\% referred to unemployment benefits, $25 \%$ to sickness benefits and $25 \%$ to disability benefits.

8. An important exception to this statement applies to workers who are paid the minimum wage. Since their wages cannot adjust downwards when there is a switch from VAT to payroll taxes, the increased tax burden is shifted to employers who will then reduce the employment of the relevant group of employees. However, before 1999 in the UK, minimum wage rules have only ever applied to a small minority of workers, so this is not relevant.

9. The $6.1 \%$ of participant inflow related to subsidised employment is an average over the period 1994-1997. In the first two years of this period the participant inflow was negligible, in the last two years it was about $12 \%$ of the labour force.

10. Apart from the increase in part-time labour there is also a strong decline in the annual numbers of working hours of a full-time worker. A full-time worker on average worked about 2250 hours in 1960. In 1990 this number was reduced to 1740. This strong decline is due to an increase in the length of the holidays and the introduction of so called 'shorter working hours' days, which all non-working days the worker can choose to have throughout the year.

11. The total number of working hours in 1960 was 7.6 billion and reaches a first maximum in 1970 with 8.3 billion working hours. After that employment in terms of working hours declined to reach a minimum of 7.4 billion in 1985 .

12. In January 1998 the number of people with a disability benefit has increased by 16,500 due to a change in administration. Until 1998 some civil servants received a different kind of benefit (invaliditeitspensioen) and were not counted as collecting disability benefits.

13. In the NL the funding of sickness benefits changed recently. Now, employers have to pay the first days of a sickness period of their employees. This change has caused the sickness statistics to fall substantially.

14. These numbers are reflected by the benefit statistics. For example, the number of primeage men in receipt of Sickness, Invalidity and Incapacity Benefit more than doubled between 1989 and 1997 (see UK Social Security Statistics, 1998, Table D1.04). 


\section{References}

Abbring, J. H., Van den Berg, G. J., Gautier, P.A., Van Lomwel, A.G.C. and Van Ours, J.C. (1998), "Displaced Workers in the United States and the Netherlands", CentER Discussion Paper No. 9896, Tilburg University.

Abbring, J.H., Van den Berg, G.J., and Van Ours, J.C. (1997) "The Effect of unemployment insurance sanctions on the transition rate from unemployment to employment", Working Paper Tinbergen Institute, Amsterdam/Rotterdam.

Abowd, J. M. and Lemieux, T. (1993), "The Effects of Product Market Competition on Collective Bargaining Agreements: the Case of Foreign Competition in Canada", Quarterly Journal of Economics, 108, 983-1014.

Bean, C. R., Layard, R. and Nickell, S.J. (1986), 'The Rise in Unemployment: A Multi-Country Study', Economica, 53, S1-S22.

Belot, M.V.K. and Van Ours, J.C. (1999), "Does the Recent Success of Some OECD Countries in Lowering Their Unemployment Rates Lie in the Clever Design of Their Labor Market Reforms?", CentER for Economic Research, Tilburg University (mimeo).

Bentolila, S. and Bertola, G. (1990), "Firing Costs and Labour Demand: How Bad is Eurosclerosis", Review of Economic Studies, 57 (3), 381.402.

Bhalotra, S. (1993), "Differentials in Urban Unemployment Rates Across Indian Sates", Wolfson College, Oxford (mimeo).

Blanchflower, D. (1996), "The Role and Influence of Trade Unions in the OECD”, Centre for Economic Performance, London School of Economics, D.P.No. 310.

Blondal, S. and Pearson, M. (1995), "Unemployment and other Non-Employment Benefits", Oxford Review of Economic Policy, 11 (1), 136-69.

Blondal, S. and Scarpetta, S. (1998), “The Retirement Decision in OECD Countries", OECD Economics Department, Working Paper No. 202, OECD, Paris.

Boone, J. and Van Ours, J.C. (1999), "Modeling Financial Incentives to Get Unemployed Back to Work", CentER for Economic Research, Tilburg University (mimeo).

Bound, J. and Burkhauser, R. V. (1997), "Economic Analysis of Programs Targeted on People with Disabilties", forthcoming in O. Ashenfelter and D. Card (eds.), Handbook of Labor Economics (North Holland). 
Bruno, M. and Sachs, J. D. (1982), "Input Price Shocks and the Slowdown in Economic Growth: The Case of UK Manufacturing”, Review of Economic Studies 49 (159), 679-705.

Calmfors, L. and Driffill, J. (1988), "Centralisation of Wage Bargaining and Macroeconomic Performance", Economic Policy, No. 6: 13-61.

Card, D. and Krueger, A. (1995), Myth and Measurement: The New Economic of the Minimum Wage, Princeton N.J. Princeton University Press.

Daveri, F. and Tabellini, G. (1997), "Unemployment, Growth and Taxation in Industrial Countries", Bocconi University (mimeo).

Dolado, J., Kramarz, F., Machin, S., Manning, A., Margolis, D. and Teulings, C. (1996), "Minimum Wages: The European Experience", Economic Policy, No.23, 319-72.

Elmeskov, J., Martin, J. and Scarpetta, S. (1998), "Key Lessons for Labour Market Reforms: Evidence from OECD Countries’ Experiences, Swedish Economic Policy Review, 5 (2), Autumn, 207-52.

Freeman, R.B. (1998), "War of the Models: Which Labour Market Institutions for the 21stcentury?", Labour Economics, 5, 1-24.

Grubb, D. (1999) Making Work Pay: the Role of Eligibility Criteria for Unemployment Benefits, Paris, OECD (mimeo).

Hartog, J. (1998) "Whither Dutch Corporatism? Two Decades of Employment Policies and Welfare Reforms", Scottish Journal of Political Economy, 46, 458-487.

Hassink, W.J.H., Van Ours J.C. and Ridder G. (1997) "Dismissal through disability", De Economist, 145, 29-46.

Gruber, J. (1997), “The Incidence of Payroll Taxation: Evidence from Chile”, Journal of Labor Economics, 15 (3, Part 2), S72-S101.

Jackman, R., Layard, R., Manacorda, M and Petrongolo, B. (1997), "European versus US Unemployment: Different Responses to Increased Demand for Skill?", Centre for Economic Performance, London School of Economics D.P. No. 349.

Knoester, A. and van der Windt, N (1987), "Real Wages and Taxation in Ten OECD Countries", Oxford Bulletin of Economics and Statistics, 49 (1), 151-69.

Layard, R., Nickell, S. and Jackman, R. (1991), Unemployment: Macroeconomic Performance and the Labour Market, (Oxford: Oxford University Press). 
Lewis, H. G. (1986), Union Relative Wage Effects: A Survey, Chicago: Chicago University Press.

Martin, J. P. (1998), "What Works among Active Labour Market Policies: Evidence from OECD Countries' Experiences”, OECD Labour Market and Social Policy, Occasional Papers No.35, OECD, Paris.

Mincer, J. (1985), "Intercountry Comparisons of Labor Force Trends and of Related Developments: An Overview”, Journal of Labor Economics, Vol. 3 (1), January, S1-S32.

Ministry of Social Affairs and Employment (1998) Sociale Nota (Social Report) 1999, Den Haag, SDU Uitgevers, 1998.

National Audit Office (1989), "Invalidity Benefit: Report by the Comptroller and Auditor General”, Her Majesty's Stationery Office, London.

Nickell, S. J. (1999), “Unemployment in Britain”, In P. Gregg and J. Wadsworth (eds.) The State of Working Britain (Manchester: Manchester University Press).

Nickell. S. J. and Layard, R. (1998), "Labour Market Institutions and Economic Performance", Forthcoming in O. Ashenfelter and D. Card (eds), The Handbook of Labor Economics (North Holland), CEP Discussion Paper No. 407, London School of Economics.

Nickell, S. J. and Bell, B. (1995), "The collapse in demand for the unskilled and unemployment across the OECD", The Oxford Review of Economic Policy, 11, 40-62.

Nickell, S. (1998) “Unemployment: questions and some answers”, Economic Journal, 108, 802816.

Nickell, S. J. (1997), "Unemployment and Labour Market Rigidities: Europe versus North America", Journal of Economic Perspectives, 11 (3), Summer, 55-74.

OECD (1997a), Literacy Skills for the Knowledge Society, Paris, OECD.

OECD (1998) Economic surveys 1997-1998, Netherlands, Paris.

OECD (1990), Unemployment Outlook, Paris: OECD.

OECD (1991), Unemployment Outlook, Paris: OECD.

OECD (1994), The OECD Jobs Study, Evidence and Explanations, Volumes I and II, Paris: OECD.

Pissarides, C. (1990), Equilibrium Unemployment Theory, (Oxford: Basil Blackwell).

Scarpetta, S. (1996), “Assessing the Role of Labour market Policies and Institutional Settings on Unemployment: A Cross Country Study”, OECD Economic Studies , 26, 43-98. 
Stewart, M. B. (1990), "Union Wage Differentials, Product market Influences and the Division of Rents", Economic Journal, 100, 1122-37.

Tyrväinen, T. (1995), "Real Wage Resistance and Unemployment: Multivariate Analysis of Cointegrating Relations in 10 OECD Economies", The OECD Jobs Study Working Paper $\underline{\text { Series }}$

Van den Berg, G.J., Van der Klaauw B. and Van Ours J.C. (1998) "Punitive sanctions and the transition from welfare to work", CentER Discussion Paper 9856, Tilburg University.

Van Ours, J.C. and Veenman, J. (1999) "The Netherlands; old emigrants - young immigrant country", CentER for Economic Research, Tilburg University (mimeo). 
Table 1

Standardised Unemployment Rates in the OECD (\%)

\begin{tabular}{|l|r|r|r|r|c|}
\hline & $\mathbf{1 9 8 3 - 8 8}$ & $\mathbf{1 9 8 9 - 9 4}$ & $\mathbf{1 9 9 5 - 9 7}$ & \multicolumn{1}{l|}{ 1998 } & \multicolumn{1}{l|}{$\begin{array}{l}\text { 1999 } \\
\text { (Jan/May) }\end{array}$} \\
\hline Netherlands & $\mathbf{1 0 . 5}$ & $\mathbf{7 . 0}$ & $\mathbf{6 . 2}$ & $\mathbf{4 . 0}$ & $\mathbf{3 . 4}$ \\
\hline UK & $\mathbf{1 0 . 9}$ & $\mathbf{8 . 9}$ & $\mathbf{8 . 0}$ & $\mathbf{6 . 3}$ & $\mathbf{6 . 2}$ \\
\hline Austria & 3.6 & 3.7 & 4.2 & 4.7 & 4.5 \\
\hline Belgium & 11.3 & 8.1 & 9.6 & 8.8 & 9.1 \\
\hline Denmark & 9.0 & 10.8 & 6.7 & 5.1 & 4.8 \\
\hline Finland & 5.1 & 10.5 & 15.2 & 11.4 & 10.7 \\
\hline France & 9.8 & 10.4 & 12.2 & 11.7 & 11.2 \\
\hline Germany (W) & 6.8 & 5.4 & 7.1 & 7.8 & 7.4 \\
\hline Ireland & 16.1 & 14.8 & 11.4 & 7.8 & 6.9 \\
\hline Italy & 6.9 & 8.2 & 10.1 & 10.1 & 10.0 \\
\hline Norway & 2.7 & 5.5 & 4.7 & 3.3 & 2.9 \\
\hline Portugal & 7.6 & 5.0 & 7.1 & 4.9 & 4.7 \\
\hline Spain & 19.6 & 18.9 & 21.9 & 18.8 & 16.6 \\
\hline Sweden & 2.6 & 4.4 & 9.8 & 8.2 & 7.3 \\
\hline Switzerland & 0.8 & 2.3 & 3.8 & - & - \\
\hline Japan & 2.7 & 2.3 & 3.3 & 4.1 & 4.7 \\
\hline Australia & 8.4 & 9.0 & 8.6 & 8.0 & 7.5 \\
\hline New Zealand & 4.9 & 8.9 & 6.4 & 7.5 & - \\
\hline Canada & 9.9 & 9.8 & 9.5 & 8.3 & 8.1 \\
\hline US & 7.1 & 6.2 & 5.3 & 4.5 & 4.3 \\
\hline
\end{tabular}

i)The OECD standardised unemployment rates are based on the ILO definition of unemployment and are computed by the OECD. However, for Italy we prefer to use the US Bureau of Labor Statistics rate 'on US concepts'. Sources: Nickell and Layard (1998), Table and OECD Employment Outlook, 1998, Table A, p.190. The rate for West Germany is based on OECD Employment Outlook (various issues) up to 1994. The 1999 data refer to the first half of the year. 
Table 2

Non-Employment Rates by Age Group (Adults) (\%)

\begin{tabular}{|l|c|c|c|c|c|c|c|c|}
\hline & \multicolumn{2}{|c|}{1979} & \multicolumn{2}{c|}{1983} & \multicolumn{3}{c|}{1990} & \multicolumn{2}{c|}{1997} \\
\hline & $25-54$ & $55-64$ & $25-54$ & $55-64$ & $25-54$ & $55-64$ & $25-54$ & $55-64$ \\
\hline Netherlands & $\mathbf{3 7 . 7}$ & $\mathbf{6 2 . 6}$ & $\mathbf{3 9 . 3}$ & $\mathbf{7 1 . 1}$ & $\mathbf{2 8 . 8}$ & $\mathbf{7 7 . 6}$ & $\mathbf{2 1 . 7}$ & $\mathbf{6 7 . 7}$ \\
\hline UK & $\mathbf{2 3 . 0}$ & $\mathbf{4 0 . 9}$ & $\mathbf{2 7 . 0}$ & $\mathbf{5 1 . 0}$ & $\mathbf{2 1 . 0}$ & $\mathbf{5 0 . 8}$ & $\mathbf{2 0 . 9}$ & $\mathbf{5 1 . 7}$ \\
\hline Belgium & & & 32.7 & 71.0 & 28.3 & 78.6 & 24.6 & 77.5 \\
\hline Denmark & & & 18.0 & 49.4 & 16.0 & 46.4 & 16.6 & 49.6 \\
\hline Finland & 17.4 & 54.4 & 14.1 & 52.7 & 12.1 & 57.4 & 21.1 & 63.8 \\
\hline France & 23.5 & 48.7 & 23.1 & 60.1 & 22.6 & 64.4 & 23.2 & 67.0 \\
\hline Germany (W) & 26.6 & 58.5 & 28.6 & 61.9 & 26.4 & 63.2 & 23.0 & 61.2 \\
\hline Ireland & 41.9 & 54.4 & 43.4 & 56.5 & 39.8 & 61.4 & 29.1 & 58.4 \\
\hline Italy & 36.8 & 77.4 & 36.0 & 77.7 & 35.1 & 78.1 & 34.1 & 73.1 \\
\hline Norway & 21.0 & 35.3 & 17.7 & 34.5 & 17.7 & 38.2 & 14.3 & 33.1 \\
\hline Portugal & 30.2 & 47.6 & 25.3 & 50.8 & 23.1 & 53.2 & 19.7 & 49.1 \\
\hline Spain & 41.2 & 53.8 & 43.9 & 58.7 & 38.9 & 63.2 & 36.9 & 65.2 \\
\hline Sweden & 12.9 & 34.7 & 11.1 & 34.5 & 8.4 & 30.6 & 18.7 & 37.0 \\
\hline Japan & 24.6 & 39.0 & 23.4 & 38.7 & 20.4 & 37.1 & 20.8 & 36.2 \\
\hline Australia & 29.5 & 57.0 & 31.5 & 60.5 & 24.2 & 58.3 & 25.0 & 56.3 \\
\hline New Zealand & & & & & 23.8 & 58.2 & 23.2 & 44.3 \\
\hline Canada & 27.5 & 48.3 & 28.1 & 52.1 & 21.6 & 53.0 & 21.7 & 54.6 \\
\hline US & 25.4 & 45.4 & 26.3 & 48.6 & 20.3 & 46.0 & 18.9 & 42.3 \\
\hline
\end{tabular}

Non-employment rates refer to the percentage of the relevant population who are not employed.

Source: OECD Employment Outlook 1996, Table B, 1999, Table C. The figures for 1979, 1983 in the UK are derived from the UK Labour Force Survey. 
Table 3

Summary of the Evidence on the Impact of Supply-Side Factors on Unemployment

\begin{tabular}{|l|c|c|}
\hline & \multicolumn{2}{|c|}{ Impact on Unemployment } \\
\hline Supply-Side Factors & Short-run & Long-run \\
\hline Benefits & ++ & ++ \\
\hline Active labour market policies & $--?$ & $--?$ \\
\hline Unions (uncoordinated bargaining) & ++ & ++ \\
\hline Unions (co-ordinated bargaining) & 0 & 0 \\
\hline Minimum wages & $+?$ & $+?$ \\
\hline Labour taxes & ++ & $+?$ \\
\hline Commodity prices & ++ & $+?$ \\
\hline Skill mismatch & + & + \\
\hline Employment protection & $+?$ & $+?$ \\
\hline
\end{tabular}




\section{Table 4 Unemployment rates and non-employment rates by sex, age group and education ${ }^{\text {a) }}$}

\begin{tabular}{|c|c|c|c|c|c|c|c|c|c|c|c|}
\hline & & Unem & yment & tes & & & Non-c & loyme & rates & & \\
\hline & & 1979 & 1985 & 1990 & 1995 & 1998 & 1979 & 1985 & 1990 & 1995 & 1998 \\
\hline NL & & & & & & & & & & & \\
\hline Total & & 6.2 & 12.8 & 5.9 & 7.0 & 4.1 & 46.1 & 47.7 & 44.8 & 42.2 & 37.8 \\
\hline Age & $25-54$ & 4.7 & 10.8 & 5.6 & 6.8 & 4.1 & 38.1 & 37.2 & 33.9 & 30.2 & 24.9 \\
\hline & $55-64$ & 6.6 & 13.2 & 3.2 & 3.2 & 2.6 & 64.8 & 72.6 & 74.2 & 74.2 & 69.5 \\
\hline Educ & Higher & 3.2 & 6.3 & 4.2 & 4.6 & 2.4 & 16.5 & 18.4 & 22.8 & 24.5 & 19.9 \\
\hline & Intermediate & 3.7 & 7.6 & 3.6 & 5.4 & 2.8 & 23.4 & 27.4 & 35.5 & 33.6 & 30.4 \\
\hline & Lower & 5.0 & 14.0 & 6.8 & 8.9 & 5.6 & 39.3 & 44.6 & 53.0 & 53.0 & 49.3 \\
\hline & None & 9.1 & 24.1 & 15.2 & 17.4 & 12.9 & 56.7 & 63.6 & 68.5 & 68.4 & 65.5 \\
\hline Male & & 4.5 & 11.2 & 5.4 & 6.4 & 3.7 & 24.5 & 31.3 & 28.9 & 28.4 & 24.7 \\
\hline Age & $25-54$ & 3.2 & 9.2 & 5.2 & 6.2 & 3.7 & 8.7 & 15.0 & 12.9 & 12.9 & 10.7 \\
\hline & $55-64$ & 5.9 & 13.1 & 3.1 & 3.1 & 2.2 & 39.9 & 55.2 & 58.4 & 61.2 & 55.6 \\
\hline Educ & Higher & 2.2 & 4.8 & 3.3 & 4.0 & 2.1 & 4.9 & 8.9 & 13.4 & 17.9 & 14.2 \\
\hline & Intermediate & 2.3 & 6.2 & 3.0 & 4.5 & 2.5 & 6.4 & 12.2 & 23.1 & 22.1 & 19.1 \\
\hline & Lower & 3.4 & 12.6 & 5.9 & 8.0 & 4.8 & 10.2 & 20.6 & 33.3 & 34.6 & 30.9 \\
\hline & None & 7.5 & 22.7 & 15.7 & 16.8 & 12.1 & 24.3 & 40.7 & 51.1 & 52.6 & 50.4 \\
\hline Female & & 10.3 & 15.7 & 6.8 & 8.1 & 4.8 & 68.3 & 64.4 & 61.2 & 56.5 & 51.3 \\
\hline Age & $25-54$ & 8.8 & 14.3 & 6.6 & 7.8 & 4.9 & 68.8 & 60.5 & 55.9 & 48.2 & 42.8 \\
\hline & $55-64$ & 9.5 & 13.6 & 3.6 & 4.0 & 4.1 & 87.5 & 88.4 & 89.1 & 87.0 & 82.7 \\
\hline Educ & Higher & 5.9 & 9.1 & 5.7 & 5.4 & 2.7 & 37.5 & 31.9 & 35.0 & 33.0 & 27.1 \\
\hline & Intermediate & 7.1 & 10.2 & 4.7 & 6.8 & 3.5 & 48.6 & 45.9 & 50.3 & 46.5 & 42.4 \\
\hline & Lower & 6.1 & 16.3 & 8.3 & 10.2 & 7.0 & 63.5 & 63.3 & 69.5 & 68.4 & 65.4 \\
\hline & None & 13.3 & 27.0 & 13.7 & 18.9 & 14.7 & 80.2 & 80.1 & 83.2 & 82.6 & 78.7 \\
\hline UK & & & & & & & & & & & \\
\hline Total & & 4.4 & 11.2 & 7.1 & 8.8 & 6.2 & 24.5 & 28.9 & 24.1 & 26.8 & 24.4 \\
\hline Age & $25-54$ & 4.6 & 9.3 & 6.3 & 7.3 & 4.9 & 23.0 & 26.1 & 20.8 & 23.0 & 21.0 \\
\hline & $55-64$ & 4.4 & 8.1 & 7.9 & 8.4 & 5.8 & 30.9 & 42.5 & 41.3 & 46.2 & 43.9 \\
\hline Educ & Higher & 2.1 & 4.1 & 2.9 & 4.5 & 3.0 & 11.0 & 13.5 & 10.8 & 13.5 & 12.0 \\
\hline & Intermediate & 3.2 & 8.2 & 5.5 & 7.9 & 4.2 & 17.0 & 19.3 & 15.8 & 21.0 & 18.4 \\
\hline & Lower & 4.0 & 11.4 & 6.9 & 9.0 & 7.1 & 16.6 & 27.0 & 21.6 & 26.1 & 24.1 \\
\hline & None & 7.1 & 16.5 & 11.6 & 14.6 & 12.2 & 30.3 & 41.6 & 3.6 .9 & 45.5 & 47.9 \\
\hline Male & & 4.0 & 11.5 & 7.1 & 10.1 & 6.8 & 9.2 & 18.8 & 15.7 & 21.5 & 18.8 \\
\hline Age & $25-54$ & 4.0 & 9.5 & 6.3 & 8.4 & 5.3 & 6.1 & 13.5 & 10.4 & 15.3 & 13.6 \\
\hline & $55-64$ & 4.5 & 8.9 & 8.8 & 10.1 & 6.8 & 20.1 & 37.7 & 37.7 & 45.4 & 41.9 \\
\hline Educ & Higher & 1.5 & 3.4 & 2.2 & 4.8 & 3.0 & 2.4 & 7.5 & 6.7 & 11.4 & 10.0 \\
\hline & Intermediate & 2.4 & 8.2 & 5.5 & 8.7 & 4.5 & 3.7 & 13.9 & 11.7 & 18.3 & 15.6 \\
\hline & Lower & 3.3 & 12.4 & 7.3 & 11.1 & 8.3 & 4.7 & 17.1 & 12.4 & 19.7 & 18.0 \\
\hline & None & 7.0 & 19.1 & 13.6 & 19.0 & 15.6 & 11.3 & 32.2 & 28.3 & 39.5 & 41.3 \\
\hline Female & & 5.2 & 10.8 & 6.5 & 6.8 & 5.3 & 41.3 & 40.3 & 33.3 & 32.8 & 30.7 \\
\hline Age & $25-54$ & 5.5 & 8.9 & 6.4 & 6.0 & 4.5 & 40.1 & 38.6 & 31.4 & 30.9 & 28.6 \\
\hline & $55-59$ & 4.2 & 6.1 & 5.6 & 4.7 & 3.5 & 48.5 & 51.5 & 48.2 & 47.8 & 47.8 \\
\hline Educ & Higher & 3.4 & 5.7 & 4.2 & 3.9 & 2.9 & 24.2 & 24.2 & 17.9 & 16.8 & 14.9 \\
\hline & Intermediate & 4.2 & 8.2 & 5.7 & 6.2 & 3.8 & 29.8 & 30.9 & 24.2 & 26.0 & 23.3 \\
\hline & Lower & 5.3 & 10.6 & 6.6 & 7.1 & 5.9 & 32.7 & 33.1 & 28.0 & 30.8 & 29.1 \\
\hline & None & 7.2 & 13.0 & 9.2 & 9.8 & 8.4 & 44.6 & 50.0 & 44.3 & 50.4 & 53.2 \\
\hline
\end{tabular}

a) Definition of NL-education: higher = higher vocational and university, intermediate = intermediate general and vocational, lower = lower general and vocational, none = primary education; Definition of UK-education: higher $=$ degree intermediate $=$ higher intermediate, lower $=$ lower intermediate. The UK total for the older age group actually refers to men aged 55-64 and women aged 55-59, 60 being the official age of retirement for women. The non-employment figures for the NL are based on official Dutch statistics and differ from the OECD numbers in Table 2 because the Dutch definition of employment is referring to jobs of at least twelve hours of work per week and the OECD/ILO definition is referring to jobs of at least one hour per week. For the NL in 1979 and 1985 in the population outside the labour force there are many persons of which the educational level is unknown. Therefore, the total non-employment rates for these years are not weighted averages of the non-employment rates distinguished by educational level. In the NL the definition of unemployment changed in 1987. The figures before and after this change are not fully comparable. Source NL: Dutch Central Bureau of Statistics; Source UK: Spring Labour Force Survey. 


\section{Table 5 Unemployment rates by immigrant status and ethnic origin}

\begin{tabular}{lccclccc}
$\begin{array}{l}\text { Immigrant } \\
\text { status }\end{array}$ & \multicolumn{2}{l}{$\begin{array}{l}\text { Netherlands } \\
\text { 1990 }\end{array}$} & 1995 & 1998 & Ethnic & UK & \\
origin & & 1990 & 1995 & 1998 \\
Natives & 5 & 6 & 3 & White & 6.8 & 8.2 & 5.7 \\
Turks & 34 & 41 & 28 & Black & 12.5 & 24.1 & 14.6 \\
Moroccans & 35 & 27 & 20 & Indian & 9.8 & 11.5 & 9.1 \\
Surinamese & 18 & 15 & 9 & Pakistani/Bangladeshi & 20.0 & 26.7 & 20.4 \\
Antilleans & 22 & 28 & 17 & Mixed and other & 11.6 & 15.9 & 12.7
\end{tabular}

Source NL: Dutch Central Bureau of Statistics; Source UK: Spring Labour Force Survey, ILO-definition

Table 6 Labour market programmes; public expenditures and participant inflows; NL and UK; averages 1994-97

\begin{tabular}{|c|c|c|c|c|}
\hline & $\begin{array}{l}\text { Publi } \\
(\% \text { o }\end{array}$ & $\begin{array}{l}\text { xpenditures } \\
\text { DP) }\end{array}$ & $\begin{array}{l}\text { Part } \\
(\%\end{array}$ & $\begin{array}{l}\text { ant inflows } \\
\text { bour force) }\end{array}$ \\
\hline - & NL & UK & NL & UK \\
\hline Public employment services & 0.37 & 0.21 & 0.0 & 0.0 \\
\hline Labour market training & 0.16 & 0.12 & 0.9 & 1.2 \\
\hline Youth measures & 0.10 & 0.13 & 0.8 & 1.0 \\
\hline Subsidised employment & 0.22 & 0.02 & 6.1 & 0.2 \\
\hline Measures for the disabled & $\underline{0.55}$ & $\underline{0.03}$ & $\underline{0.2}$ & $\underline{0.2}$ \\
\hline Total active measures & 1.40 & $\overline{0.51}$ & $\overline{8.0}$ & $\overline{2.6}$ \\
\hline Unemployment compensation & 3.45 & 1.33 & & \\
\hline Early retirement ${ }^{\text {a) }}$ & $\underline{0.29}$ & $\underline{0.00}$ & & \\
\hline Total passive measures & 3.74 & 1.33 & & \\
\hline Total & 5.14 & 1.84 & & \\
\hline a) For labour market reasons & & & & \\
\hline
\end{tabular}


Table 7

\section{The Long-Run Impact of Changes in Institutions on the Equilibrium Unemployment Rates of NL and UK (Early 80s to Mid 90s)}

\begin{tabular}{|c|c|c|c|c|c|}
\hline & & \multicolumn{2}{|c|}{ NL } & \multicolumn{2}{|l|}{ UK } \\
\hline Institution & $\begin{array}{c}\text { Impact of a } \\
10 \% \text { pt. Rise } \\
\text { on } u^{*}\end{array}$ & $\begin{array}{c}\text { Increase } \\
\% \text { pt. }\end{array}$ & $\begin{array}{c}\text { Change in } u^{*} \\
(\%)\end{array}$ & $\begin{array}{c}\text { Increase } \\
\% \text { pt. }\end{array}$ & $\begin{array}{l}\text { Change } \\
\left.\text { in u* } u^{*} \%\right)\end{array}$ \\
\hline $\begin{array}{l}\text { Union } \\
\text { Density }\end{array}$ & 0.896 & $-9.3(80-94)$ & -0.83 & $-16.4(80-94)$ & -1.47 \\
\hline $\begin{array}{l}\text { Union } \\
\text { Coverage }\end{array}$ & 0.930 & $6.2(82 / 4-94)$ & 0.58 & $-13.4(82 / 4-94)$ & -1.25 \\
\hline $\begin{array}{l}\text { Active } \\
\text { Labour } \\
\text { Market } \\
\text { Policies } \\
\end{array}$ & -1.11 & $9.8(85-96)$ & -1.09 & $-1.4(85-96)$ & 0.16 \\
\hline Coordination & $\begin{array}{l}\quad-2.53 \\
\text { (impact of unit } \\
\text { rise of index) }\end{array}$ & $\begin{array}{c}1(83-96) \\
\text { (rise in index) }\end{array}$ & -2.53 & $0(83-96)$ & 0 \\
\hline $\begin{array}{l}\text { Benefit } \\
\text { Replacement } \\
\text { Rate }\end{array}$ & 1.11 & $-3.7(81 / 5-95)$ & -0.41 & $\begin{array}{c}-4.3 \\
(81 / 5-95)\end{array}$ & -0.48 \\
\hline Tax Wedge & 1.18 & $-2.0(81 / 5-94)$ & -0.24 & $\begin{array}{c}-6.0 \\
(81 / 5-94)\end{array}$ & -0.72 \\
\hline Total & & & -4.52 & & -3.76 \\
\hline
\end{tabular}

Notes: i) The impact coefficients in the first column are generated by averaging the coefficients as they appear in Nickell and Layard (1998), Table 15, Col.1; Scarpetta (1996), Table 1, Col.3; Elmeskov et al. (1998), Table 2, Col. 1 (or Col. 5 for Union Density). Union coverage only appears in Nickell and Layard (1998) as an index and its impact has been converted by assuming that for those countries whose union coverage is below $25 \%$, the average value is 20 and for those whose union coverage is above $70 \%$, the average is 84.6 (these are the actual numbers for 1994). The Nickell/Layard equation has $\log \mathrm{u}$ as the dependent variable, so to convert we use $\mathrm{u}=7.91$.

ii) The change data for NL, UK are as follows: union density, union coverage, OECD (1994), Chapter 5, OECD (1997), Chapter 3 (with some interpolation); active labour market policies (spending per person unemployed as a percentage of GDP per member of the labour force), Martin (1998), Table 2; coordination (index running from 2 to 6), Nickell and Layard (1998) and Belot and van Ours (1999); benefit replacement rate, OECD average data, corresponding to the final column in OECD (1994), Table 8.1; tax wedge (sum of payroll, income and consumption tax rates), Centre for Economic Performance (LSE), OECD Data Set. 
Table 8 Part-time labour (\% of total)

\begin{tabular}{lcccccc} 
& Males & \multicolumn{5}{c}{ Females } \\
& 1983 & 1990 & 1998 & 1983 & 1990 & 1998 \\
NL & 7 & 15 & 18 & 50 & 59 & 68 \\
UK & 3 & 5 & 9 & 42 & 43 & 45 \\
EU-15 & 3 & 4 & 6 & 26 & 28 & 33
\end{tabular}

Source: Eurostat, Labour Force Surveys

Table 9 Sickness and disability rates

\begin{tabular}{lllllll} 
& \multicolumn{2}{l}{ Sickness } & \multicolumn{2}{l}{ Disability } & Total \\
& 1990 & 1995 & 1990 & 1995 & 1990 & 1995 \\
NL & 7.2 & 5.2 & 8.9 & 8.0 & 16.1 & 13.2 \\
UK & 2.6 & 3.5 & 3.4 & 4.9 & 5.8 & 8.4
\end{tabular}

Source: Dutch Ministry of Social Affairs and Employment

Table 10 Disability benefits (NL) and sickness inactivity rates (UK); total and by age group; males and females $(\% \text { of relevant population })^{\text {a) }}$

\begin{tabular}{|c|c|c|c|c|c|c|c|c|c|c|}
\hline & & & NL & & & & & UK & & \\
\hline & 1980 & 1985 & 1990 & 1995 & 1998 & 1979 & 1985 & 1990 & 1995 & 1998 \\
\hline Total & 6.9 & 7.6 & 8.5 & 8.1 & 8.5 & 2.6 & 3.9 & 4.6 & 7.4 & \\
\hline Males & & & & & & & & & & \\
\hline Total & 10.2 & 10.9 & 11.3 & 10.3 & 10.1 & 3.1 & 4.5 & 5.2 & 8.2 & \\
\hline $25-54$ & 8.8 & 9.4 & 9.8 & 8.3 & 8.0 & 1.7 & 2.2 & 2.8 & 4.6 & \\
\hline $55-64$ & 34.7 & 36.9 & 36.0 & 33.1 & 32.0 & 8.0 & 12.8 & 15.4 & 21.9 & \\
\hline Female & & & & & & & & & & \\
\hline Total & 3.6 & 4.3 & 5.6 & 5.8 & 6.7 & 2.0 & 3.3 & 4.0 & 6.5 & \\
\hline $25-54$ & 3.5 & 4.1 & 5.5 & 5.5 & 6.4 & 1.5 & 2.5 & 3.2 & 5.4 & \\
\hline $55-64$ & 8.9 & 10.8 & 12.8 & 13.7 & 14.9 & 4.5 & 8.5 & 8 & 16.2 & \\
\hline
\end{tabular}

a) NL: number of disability benefits. Source: NL National Institute for Social Insurance; UK: rates are a percentage of the relevant working age population who report that they are inactive because of "sickness" which includes any form of ill-health or disability. 1979-83 are based on question "reason not looking for work" for the inactive. 1985-91 are based on questions "reason not looking for work in last week" and "reason not looking for work at all" for the inactive. 1992-1998 are based on questions "reason not looking for work in last 4 weeks" and "reason not want work in last 4 weeks" for the inactive. Source: UK Labour Force Survey, Spring Quarter. 
Box 1

The Relationship between the Beveridge Curve, Phillips Curve and Equilibrium Unemployment

The Beveridge Curve. For simplicity suppose the only job seekers are the unemployed, $\mathrm{U}$ in number, and that the labour force, $\mathrm{L}$, is constant. Consider the function which relates the number of new hires, $\mathrm{H}$, to the number of vacancies, $\mathrm{V}$, and the number of effective job seekers, cU, where $\mathrm{c}$ is the average job search effectiveness of the unemployed. This is known as the hiring function and has the form

$$
\mathrm{H}=\mathrm{h}(\mathrm{V}, \mathrm{cU}) \quad\left(\mathrm{h}_{1}>0, \mathrm{~h}_{2}>0\right)
$$

Job search effectiveness, c, refers to any factor which makes job seekers search more intensively (e.g. less generous benefit systems) or makes job seekers more attractive to firms (e.g. certain active labour market policies) or encourages firms to be less choosy and search more intensively (e.g. lower levels of employment protection).

If $s$ is the (exogenous) inflow rate into unemployment, then the steady state, the total inflow $=$ total outflow, or

$$
\mathrm{sN}=\mathrm{h}(\mathrm{V}, \mathrm{cU})
$$

where $\mathrm{N}$ is employment. If $\mathrm{h}$ has constant returns, this may be rewritten as

$$
\mathrm{s}=\mathrm{h}\left(\mathrm{v}, \frac{\mathrm{cu}}{1-\mathrm{u}}\right)
$$

which is the Beveridge Curve, a downward sloping relationship between the vacancy rate $\mathrm{v}=\mathrm{V} / \mathrm{N}$ and the unemployment rate $\mathrm{u}=\mathrm{U} / \mathrm{L}$. So long as $\mathrm{u}$ is small, this may be rewritten as

$$
\mathrm{s} \simeq \frac{1}{\mathrm{~L}} \mathrm{~h}(\mathrm{~V}, \mathrm{cU})
$$

In practice, the economy is rarely in steady state and the $(\mathrm{V}, \mathrm{U})$ locus tends to cycle around the steady state curve in anti-clockwise loops (see Pissarides, 1990, for details). The key point for our purpose is that anything that tends to raise $\mathrm{c}$ or lower $\mathrm{s}$ will shift the Beveridge curve to the left. 


\section{Box 1 continued}

The Phillips Curve and Equilibrium Unemployment. Pressure on wages coming from workers depends on the ease with which a worker of average effectiveness can find a job if she becomes unemployed, namely $\mathrm{H} / \mathrm{cU}$. Pressure on wages from firms depends, inversely, on the ease with which it can fill vacancies, namely $\mathrm{H} / \mathrm{V}$. So we would expect both these factors to influence wages. However, the hiring function (1) implies that

$$
1=\mathrm{h}(\mathrm{V} / \mathrm{H}, \mathrm{cU} / \mathrm{H})
$$

which ensures that $\mathrm{H} / \mathrm{cU}$ and $\mathrm{H} / \mathrm{V}$ are monotonically and inversely related, so only one of these is required in a wage equation. We shall use $\mathrm{cU} / \mathrm{H}$ as a factor exerting downward pressure on wages. But note that in steady state $\mathrm{H}=\mathrm{sN}$, so $\mathrm{cU} / \mathrm{H} \simeq \mathrm{cu} / \mathrm{s}$ and we may write our wage equation as

$$
(w-p)=\gamma_{0}-\gamma_{1} c u / s-\gamma_{2}\left(p-p^{e}\right)+z_{w}
$$

where $\mathrm{w}, \mathrm{p}$ are $\log$ wages, prices and $\mathrm{z}_{\mathrm{w}}$ reflects any other factors which put upward pressure on wages given a fixed stock of unemployed job seekers of given effectiveness. ( $\left.p-p^{e}\right)$ reflect inflation surprises which will obviously tend to lower real wage outcomes. In practice we suppose that these correspond to changes in the rate of inflation, so $\left(p-p^{e}\right)=\Delta^{2} p$ (note $\Delta^{2} p=\Delta$ $(\Delta \mathrm{p})$ where $\Delta \mathrm{p}$ is the inflation rate). If we suppose prices are determined on a simple mark-up basis, then we have a price equation of the form

$$
(\mathrm{p}-\mathrm{w})=\beta_{\mathrm{o}}-\beta_{\mathrm{l}} \mathrm{u}+\mathrm{z}_{\mathrm{p}}
$$

where $z_{p}$ reflects any factor which raises prices at any given level of demand (captured by u). Eliminating (w-p) from (4), (5) yields the Phillips Curve ${ }^{1}$.

$$
\Delta^{2} \mathrm{p}=\frac{1}{\gamma_{2}}\left(\gamma_{0}+\beta_{0}+\mathrm{z}_{\mathrm{w}}+\mathrm{z}_{\mathrm{p}}-\left(\beta_{1}+\gamma_{1} \mathrm{c} / \mathrm{s}\right) \mathrm{u}\right)
$$

Notice that $z_{\mathrm{w}}, \mathrm{z}_{\mathrm{p}}$, s/c are all factors which will raise inflationary pressure at constant unemployment, so they will all raise the equilibrium rate. This is confirmed by noting that the equilibrium rate, $\mathrm{u}^{*}$, defined as the value of $\mathrm{u}$ corresponding to stable inflation, $\Delta^{2} \mathrm{p}=0$, is given by

$$
\mathrm{u}^{*}=\left[\beta_{0}+\gamma_{0}+\mathrm{z}_{\mathrm{p}}+\mathrm{z}_{\mathrm{w}}\right] /\left(\beta_{1}+\gamma_{1} \mathrm{c} / \mathrm{s}\right)
$$

The key point to note here is that anything which causes the Beveridge Curve to shift to the left (c up or s down) will tend to lower the equilibrium rate, $\mathrm{u}^{*}$. 


\section{Box 2 \\ The Wassenaar Agreement}

Friday November 5, 1982 in Wassenaar, a village near The Hague, in the home of the chairman of the employers' federation an agreement was established between this federation and the leading union federation. This so-called Wassenaar agreement was established under the pressure of sharply rising unemployment and rapidly declining employment. Employers agreed with working time reduction. The unions agreed to give up price indexation of wages and to moderate wage claims. It was also agreed that obstacles to temporary work would be removed. Persons with part-time jobs would get full social security coverage (including after 6 months the accumulation of pension rights), while their wages would depend on the amount of work they actually provided. More specifically unions agreed that working time reduction and part-time labour should not increase labour costs or reduce operating hours of firms.

Although the agreement was bilateral between unions and employers, at the same time the government agreed to get its budget under control and reform social security. In the course of the 1980s benefit replacement rates were reduced from 80 to $70 \%$ and the minimum wage was fixed for a decade.

The Wassenaar Agreement marks a change in labour relations, from a period of frictions and ideological differences of opinion towards a more consensual approach in labour relations.

Although the actual meaning is sometimes questioned in hindsight, the Wassenaar agreement is sometimes considered as the start of the period of the 'Dutch model'. In this period many detailed agreements between unions and employers were established with respect to training, the functioning of the labour market and the labour market position of specific groups. 


\section{Box 3 \\ New Deal Policies in the UK}

The Blair government (elected in May 1997) is introducing a series of new welfare-towork initiatives for a variety of groups including young long-term unemployed, older long-term unemployed, single parents, disability benefit recipients. The New Deal for young people was the first, introduced nationally on April $6^{\text {th }}, 1998$. The process is as follows:

Eligibility: Those aged 18-24 who have been claiming unemployment benefit continuously for 6 months become eligible for New Deal when they reach the 6 month threshold. At that point, their participation is mandatory.

The Process: Those joining first enter a Gateway period lasting up to four months, during which the Employment Service and their partners will work with them to improve their employability and to find unsubsidised jobs for as many as possible. Thos who do not find a job will then move onto one of four options lasting for six months i) a period of subsidised employment, ii) a course of full-time education/training, iii) a job with an Environment Task Force, iv) a job in the Voluntary Sector. They do no have the option of continuing to draw benefit.

If the client reaches the end of their option and still has not obtained a job, they will normally re-claim unemployment benefit and will enter a follow-through period. During this, they will receive intensive help to find a job.

The other New Deal policies are similar in style but differ in the detail. The main aim is to prevent individuals remaining on benefit for long periods. 

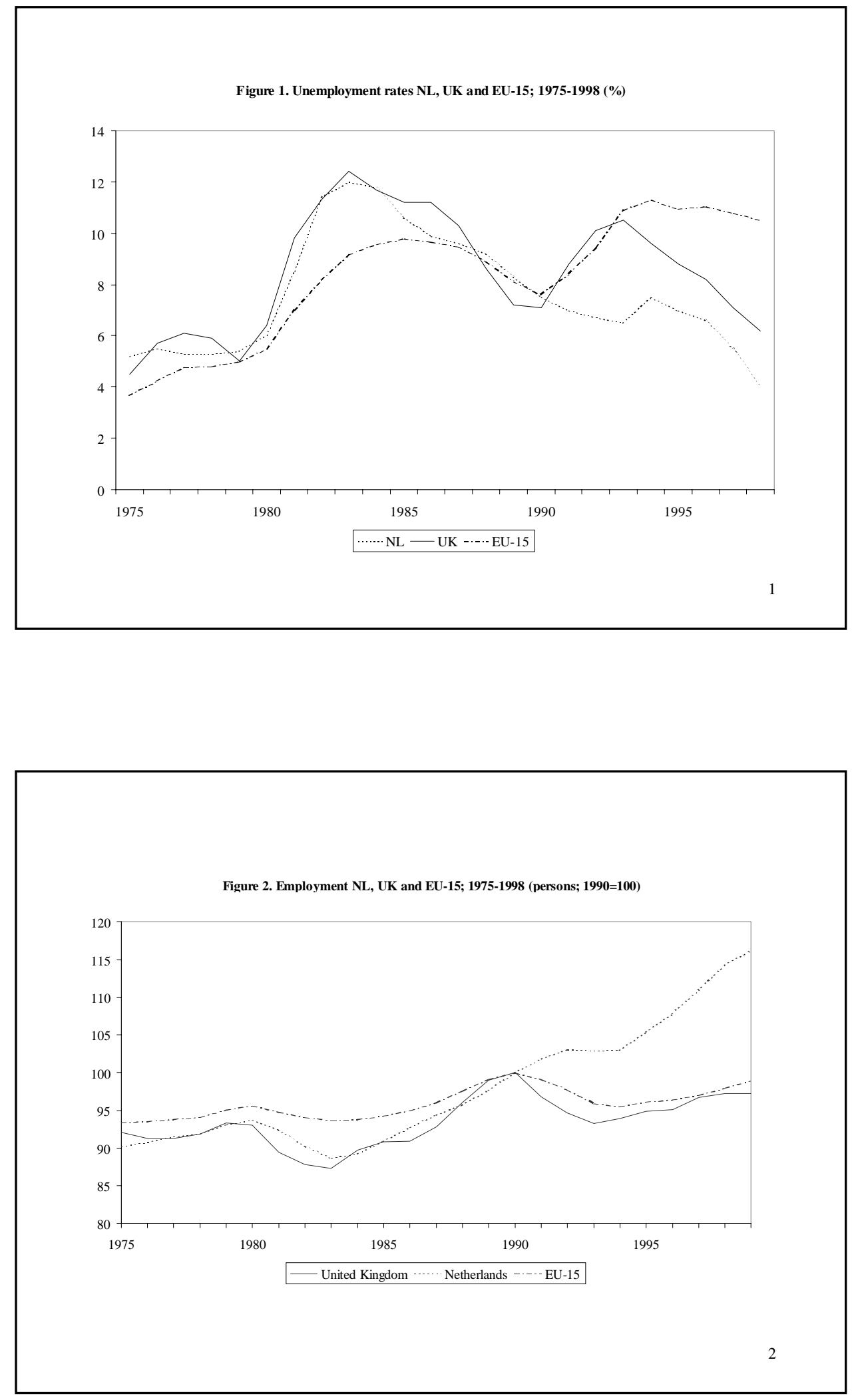

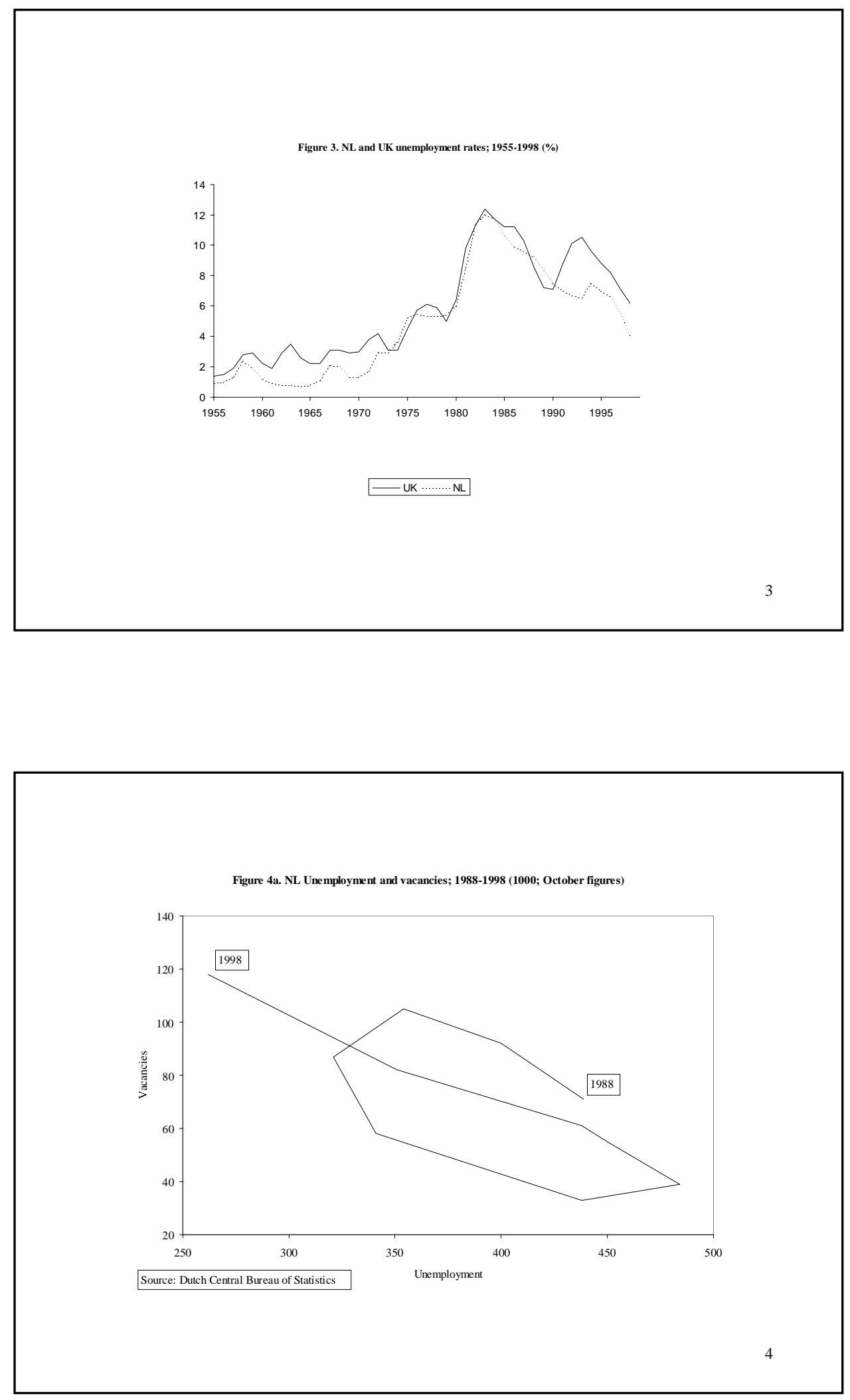

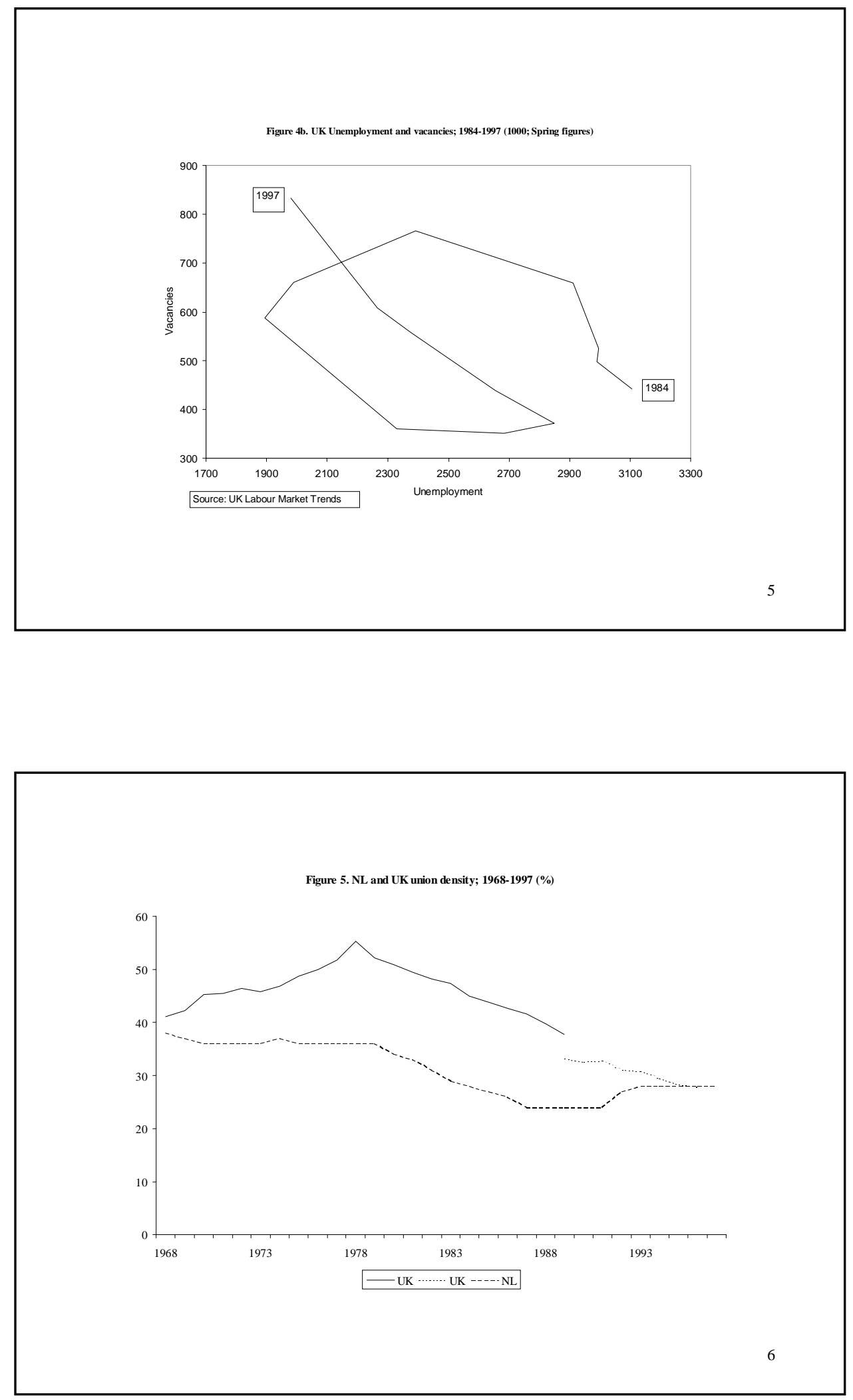

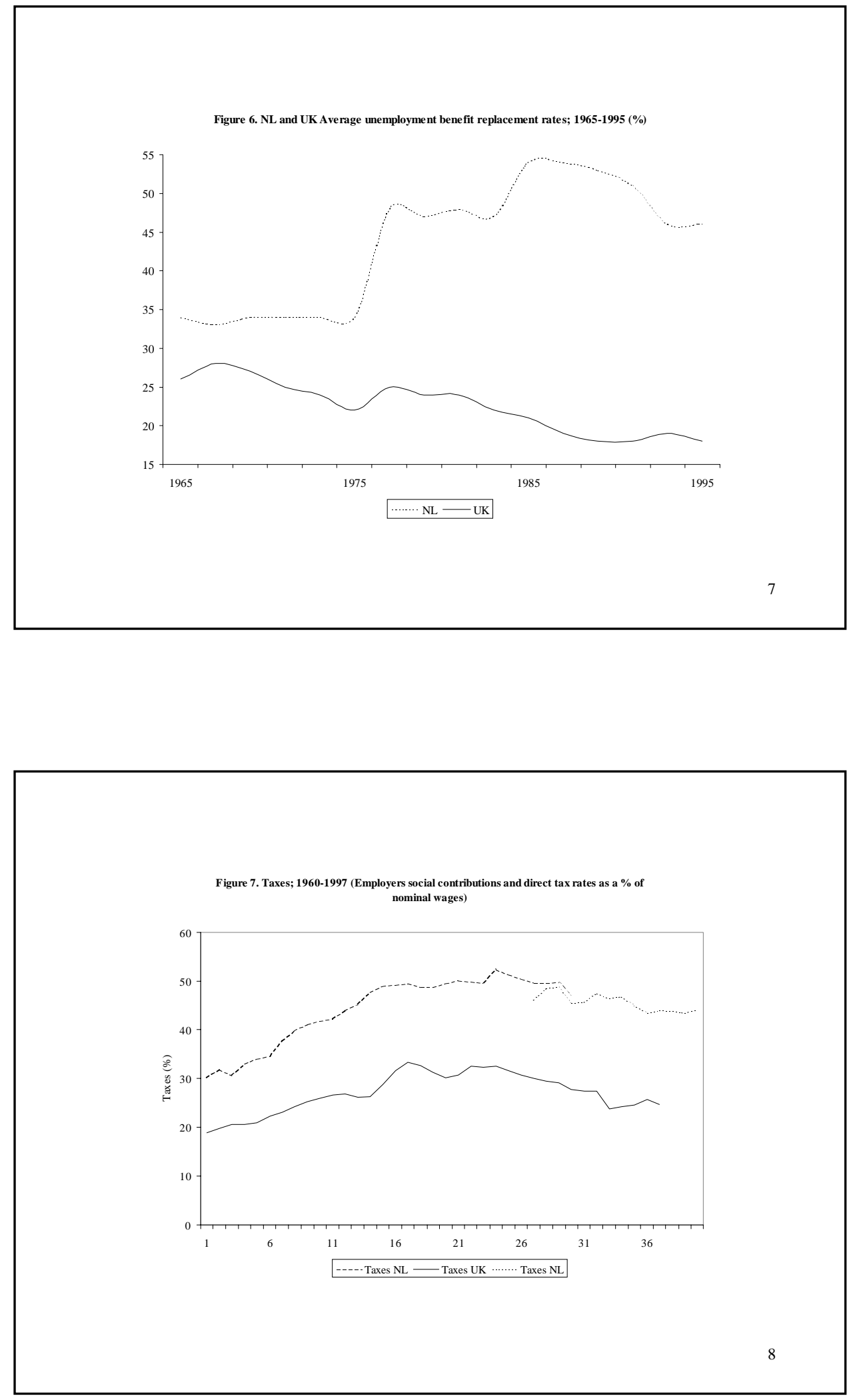


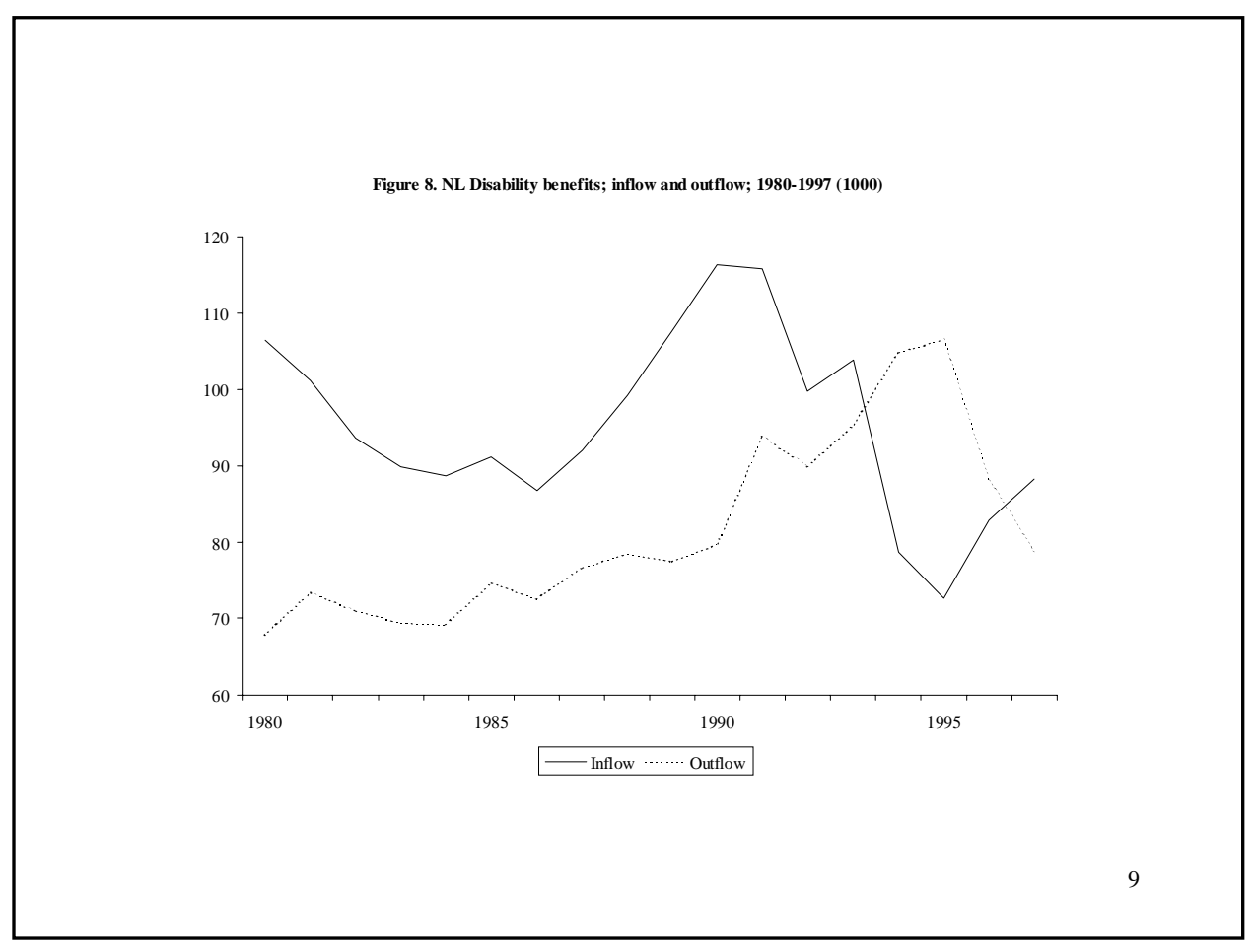

5 